\title{
Curbing the Challenges in Recent Treatment Guideline for Early Management of Individuals with Traumatic Spinal Cord Injury: Recommendation for Therapeutic Hypothermia
}

\author{
Stephen Sunday Ede ${ }^{1,2^{*}}$, Chigozie Ikenna Uchenwoke ${ }^{1}$, Kayode Israel Oke ${ }^{3}$, \\ Chigozie Okwudili Obaseki ${ }^{2,3}$ and Franklin Onyedinma Irem ${ }^{1}$ \\ ${ }^{1}$ Department of Medical Rehabilitation, Faculty of Health Sciences and Technology, College of \\ Medicine, University of Nigeria, Enugu Campus, Enugu State, Nigeria. \\ ${ }^{2}$ Department of Physiotherapy, University of Benin Teaching Hospital, Benin City, Edo State, Nigeria. \\ ${ }^{3}$ Department of Physiotherapy, University of Benin, Benin City, Edo State, Nigeria.
}

Authors' contributions

This work was carried out in collaboration among all authors. Authors SSE and CIU designed the study, performed the statistical analysis, wrote the protocol and wrote the first draft of the manuscript.

Authors SSE, KIO and COO managed the analyses of the study. Authors SSE, KIO and FOI managed the literature searches. All authors read and approved the final manuscript.

Article Information

DOI: 10.9734/ARRB/2020/v35i1130296 Editor(s):

(1) Dr. Md. Torequl Islam, Federal University of Piaui, Brazil.

Reviewers:

(1) R. Ravikumar, MGM Health Care, India

(2) Md. Sadique Shaikh, Aditya Institute of Management Studies and Research (AIMSR), India. Complete Peer review History: http://www.sdiarticle4.com/review-history/61506

Review Article

Received 03 August 2020

Accepted 09 October 2020

Published 02 November 2020

\begin{abstract}
Background: There has been little prognosis in improving function after a complete spinal lesion. The viewpoint that little can be done to improve motor function after complete $\mathrm{SCl}$ seems conceptually and scientifically part of the past. With advance in medicine, better neurological outcome is long expected.

Objectives: The purpose of this review is to explore the challenges in recent treatment guidelines' for early management of patient with $\mathrm{TSCl}$ and to draw recommendation for Therapeutic hypothermia.
\end{abstract}


Methods: We conducted a scoping study review comprising 28 studies (2010 to 2020) to identify and examine the research literature related to challenges' in recent treatment guidelines' for early management of patient with $\mathrm{TSCl}$.

Findings: 28 studies were reviewed. Most cited challenges were surgical timing (26\%), followed by controversy on the application of MPS (28.6\%). In each of the studies, various challenges of acute stage interventions were outline with poor common standards and recommendations for clinical practices. Surgical decompression (16 papers) was the most cited intervention. Generally, result showed that despite the progress that has been made in the acute management of patients with $\mathrm{SCl}$, neurological outcomes have not improved significantly in recent decades.

Conclusion: Key early interventions are increasingly being recognized; combined Neuroprotective and neuroregenerative care are probably more effective and they inspire current and future research. We concluded that an evidence based guidelines for TH would help reduce the doom experience around complete SCls. Thus there is a need to better define the beneficial effect of $\mathrm{TH}$ on the injured SCl.

Keywords: Traumatic spinal cord injury; emergency care; treatment guideline; therapeutic hypothermia.

\section{ABBREVIATIONS}

$\begin{array}{ll}\text { TSCI } & \text { : Traumatic Spinal Cord Injury } \\ \text { TH } & \text { : Therapeutic Hypothermia } \\ \text { MPS } & \text { : Methylprednisolone } \\ \text { SCIWORA } & \text { : Spinal cord injury without radiological abnormality } \\ \text { SCIWORET } & \text { : Spinal cord injury without radiological evidence of trauma }\end{array}$

\section{INTRODUCTION}

According to the World Health Organisation (WHO, 2013), there is no reliable estimate of global prevalence of Spinal Cord Injury (SCl), but it is estimated that annual global incidence varies from 40 to 80 cases per million population, which means between 250,000 to 500,000 people sustain $\mathrm{SCl}$ every year. The prognosis of patients with neurological disorders in Africa is far from reproducible parameters. Oftentimes, these conditions produce devastating physical, social, and vocational impairment. Etiologically, more than $90 \%$ of SCl cases are traumatic and caused by incidences such as traffic accidents, violence, sports or falls. SCl has been associated with very high mortality rates. Yet today, only in developed countries, $\mathrm{SCl}$ can be viewed less as the end of a worthwhile or productive life and more as personal and social challenges that can be successfully overcome [1].

$\mathrm{SCl}$ is a medically complex and life-disrupting trauma, often tagged to be one of the greatest calamities that can befall man [2]. It is described as damage to the spinal cord, conus medullaris and cauda equina that causes temporary or permanent loss in its sensory, motor and/or autonomic function in the parts of the body served by the spinal cord below the level of the injury [3]. Damage to the spinal cord may be traumatic or non-traumatic. Traumatic $\mathrm{SCl}$ can result from many different causes - including falls, road traffic injuries, occupational and sports injuries, and violence. Non-traumatic $\mathrm{SCl}$, on the other hand, usually involves an underlying pathology - such as infectious disease, tumour, musculoskeletal disease such as osteoarthritis, and congenital problems such as spina bifida [1].

The extent and severity of sensory, motor and autonomic loss from SCl depends not only on the level of injury to the spinal cord, but also on whether the lesion is complete or incomplete and time of intervention [3]. According to the American Spinal Injury Associations (ASIA) classification of $\mathrm{SCl}$, an $\mathrm{SCl}$ is considered complete if there is no sensory and motor function at S4-S5, while some sensory and or motor function is preserved below the level of injury in incomplete SCI [1]. While considerable function can be recovered if the injury is 'incomplete', there has been little prognosis in improving function after a motor and/or sensory complete lesion. Presently, literature holds that, those with a complete $\mathrm{SCl}$ are unlikely to regain function below the level of injury $[4,5]$.

\subsection{What Goes Wrong in a TSCI?}

The pathophysiology of TSCl all begins with an impact on the spine that fractures or dislocates 
vertebrae. The initial mechanical forces delivered to the spinal cord at the time of injury is referred to as primary injury where "displaced bone fragments, disc materials, and/or ligaments bruise or tear into the spinal cord tissue" [6]. Followed by associated spinal cord contusion or laceration, petechial hemorrhage formation, axonal shearing, and vascular disruption [7]. The most common form of primary injury is impact plus persistent compression, which typically occurs through burst fractures with bone fragments compressing the spinal cord or through fracture-dislocation injuries $[7,8]$. Regardless of the form of primary injury, these forces directly damage ascending and descending pathways in the spinal cord and disrupt blood vessels and cell membranes [9]. Causes spinal shock, systemic hypotension, vasospasm, vasoconstriction and vascular thrombosis, ischemia, cellular ionic imbalance, free radical formation, increased interstitial pressure, release of vaso-active protein, cellular membrane lipid peroxidation, excite toxic glutamine release and neurotransmitter accumulation [10,11]. Overall, the extent of the primary injury determines the severity and outcome of SCI [12,13].

\section{CHALLENGES IN TSCI CLINICAL GUIDELINE}

Spinal cord injury need not be a death sentence. The perspective that slight chances of improvement in motor function after complete $\mathrm{SCl}$ seems conceptually and scientifically part of the past, not the present. But this requires effective emergency response and proper rehabilitation services, which are currently the focus of research.

To date, the most effective clinical treatment to limit tissue damage following primary injury is early surgical decompression (< $24 \mathrm{~h}$ post-injury) of the injured spinal cord [12,13]. However, in several occasions, many factors pose challenges to the feasibility of having this surgical intervention within the safe period. There is few other advanced line of care following TSCls but most of these lacks enough class 1 evidence in the literature or are yet to be properly translated to clinical practice. Such treatment guidelines from advances in medicines include; Cryosurgery: Aimed at correcting the inflammatory effect, Spinal stimulation: aim at restoring motor functions, and cell mediated therapy.

Other classical lines of care after early surgical decompression have shown little or no clinical benefit. For instance, the most emphasized routine spinal immobilization in trauma patients which was believed to be the best way to prevent further injury to the spinal cord following a traumatic injury [14], and, that it was in the best interests of all patients whose injuries had not yet been assessed. However, this recommendation is true for checking against more mechanical damages especially in an incomplete or a SCI without radiological abnormalities (SCIWORA) and in $\mathrm{SCl}$ with no radiological evidence of trauma (SCIWORET). In a potential complete $\mathrm{SCl}$, this recommendation is without enough evidence [15]. It has been suggested that the risk of neurological injury due to inadequate immobilization may be over-estimated [16]. Excluding mechanical injury, there are well established mechanisms for spinal injury progression. This includes; (see Fig. 1.) haematoma, cord oedema, hypotension, inflammation and vascular changes such as reduced microcirculation $[17,18]$. Therefore, it is critical to understand the cellular and molecular mechanisms of $\mathrm{SCl}$ and develop new effective treatments for this devastating condition.

Thumbikat et al. [18] highlighted the cases of several patients, including a patient who had a fall on steps and fractured his cervical spine. The ambulance crew placed him in a hard collar and scoop stretcher while he was transported to the hospital. On admission, his powers were preserved and normal in all limbs. During 6person inline transfer to another specialist unit, he suffered an abrupt shooting pain in one side of the body and there was an abrupt reduction in blood pressure. He became tetraplegic and later ended with a partial recovery. This scenario demonstrates that a standard spinal immobilization protocol can be quite harmful to some patients [18].

Literature has also ruled out the options of using Intravenous (IV) methylprednisolone [19]. A bottom-line finding is a timely, appropriate prehospital management, neuroprotective strategies, quick recognition of suspected spinal cord injury, rapid evaluation and initiation of injury management, prevention of associated complications and individualized patient-targeted rehabilitation programs provided by a specialized interdisciplinary team are crucial to optimize the outcome after SCl [20]. However, there is a gap in the role of physiotherapy care, as it is presently being limited to the rehabilitation phase in $\mathrm{SCl}$ with gap in its potential acute neural care. 


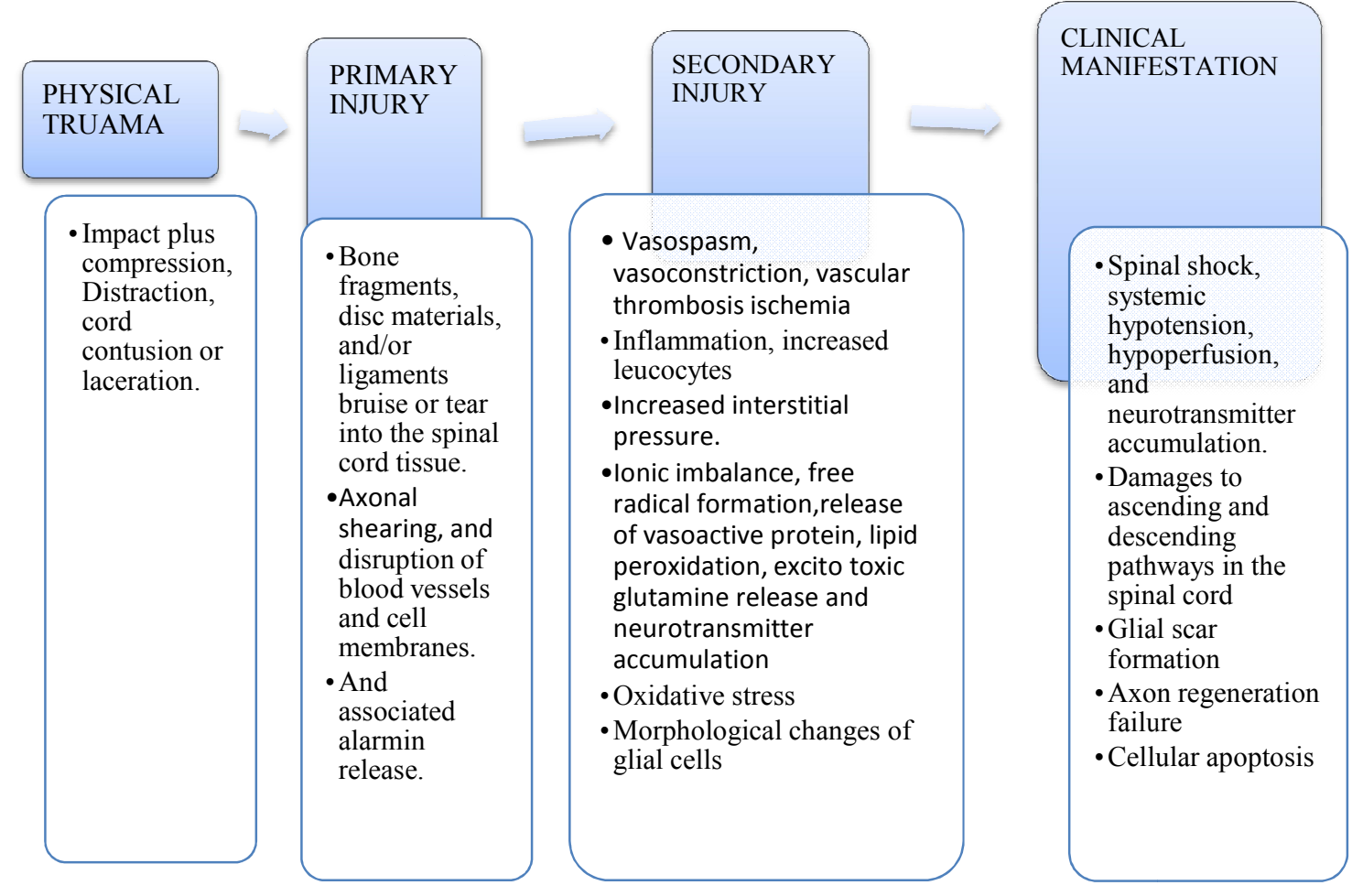

Fig.1. Primary and secondary injury mechanism after TSCI

Physiotherapy principles will suitably initiate neuroprotective strategies through the use of therapeutic hypothermia. An acute $\mathrm{TSCl}$, like every other acute injury to the body tissues $[21,22]$, could benefit from localized therapeutic hypothermic care $[23,24,25]$. The final extent of the spinal cord damage results from primary and secondary mechanisms that start at the onset of the injury and goes on for days, and even weeks, after the event. The right treatment from the onset may help decrease the healing time and prevent further complications. The early stages of the secondary injury are thought to be critical areas where medical intervention can benefit the patient $[26,27]$.

It is thus paramount, instead of trusting the recovery of neurological functions to fate in a postural reduction or immobilization, much emphasis should rather be placed on arresting the ongoing pathophysiological process. This work aims to recommend a localized therapeutic hypothermia as a potential focus in the treatment guideline for acute care in TSCl.

\section{STUDY OBJECTIVE}

The objectives of this scoping review are: [1] to collate and appraise all available published literature, which understudies recent treatment guidelines' for managing patient with TSCl [2]. To elucidate the pathophysiology of TSCl and unravel the underlying cellular and molecular mechanisms of tissue degeneration and repair in the injured spinal cord [3]. To outline common standards and supporting evidence for the neurological care of patients within the first year after SCl [4]. To explore prevention strategies, and the evidence in literature on the effectiveness of the various treatment choices, including their challenges, and; [5] to draw out an evidence and recommendations for localized therapeutic hypothermia; as a key addition in the treatment guidelines following a TSCl.

\section{REVIEW OF CURRENT TREATMENT GUIDELINE}

The methodologically guidelines for scoping study, as proposed by Arksey and O'Malley [28] will be used for this review to conduct a comprehensive and systematic search of the literature and to draw out an evidence and recommend localized therapeutic hypothermia; to be considered as a key addition in the treatment guidelines following a TSCl. This review follows the six-stage scoping review framework outlined by Arksey and O'Malley [28]. 


\subsection{Stage One: Identify the Research Question}

A five-part research question will be in focus: World Health Organization [1] what is the pathophysiology of $\mathrm{TSCl}$ and the underlying cellular and molecular mechanisms of tissue degeneration and repair in the injured spinal cord? Azeez AL et al. [2] what are the common standards and supporting evidence for the neurological care of patients with TSCls? Singh A et al. [3] what are the challenges in the recent early neurological care of patients with TSCls? Waters RL et al. [4] how does interdisciplinary neurological team address the pathophysiology of TSCl? And [5] will a localized therapeutic hypothermia following a TSCl help in improving the clinical outcomes of TSCls?

\subsection{Stage Two: Identify Relevant Studies}

With a comprehensive search of the literature, relevant peer reviewed journals articles published between (2010-2020) were sought from the following eight [8] electronic databases; AMED, Cochrane databases, PubMed, PubMed Central, MEDLINE, ProQuest, Embase, Web of Science Core Collection. The key search terms included: 'traumatic spinal cord injury AND emergency OR Acute OR early AND care OR management OR treatment OR intervention AND challenges OR controversies AND guideline OR recommendation'.

In addition, a thorough search of the reference lists of selected articles was undertaken and the use of Google Scholar to access any other primary sources and full text versions of articles was utilized. We exported all literature sources from each of the database searches into a references and bibliographic management software program.

\subsection{Stage Three: Study Selection}

The inclusion criteria are as follows; (1) articles written in English; (2) published original peerreviewed journals; (3) those with an approved ethics statement; (4) studies which investigates guidelines in early neurological care for TSCls; and (5) in a population sample of TSCls only.

For the purpose of this study, exclusion criteria include; (1) Articles that were considered poorly conducted; (2) extremely small sample sizes; (3) articles examining the various interdisciplinary care for TSCls but without direct focus on neurological outcomes.

The second author reviewed each paper with the lead author to decide whether it should be included. Using the above key search terms, we identified 3462 articles across the eight databases. Of which, 28 were included in this review (see Fig. 2).

\subsection{Stage Four: Charting the Data}

The fourth stage involved developing a framework for data charting. A summarizing process, in a standardized manner, was executed as described by Arksey and O'Malley [28]. A data charting table was used for summarizing each primary reviewed article by; author, year, country of origin, study aim, early neurological care, challenges in the neurological care outlined, study design, study methods and sample size, an abridged summary of the findings and limitations for each study.

The second reviewer then validated the data by reviewing each selected article based on the inclusion/exclusion criteria; an agreement was reached on the information presented in Table 1.

\subsection{Stage Five: Collating, Summarizing and Reporting Results}

This fifth stage of the review involved collating the various interdisciplinary spinal neurological interventions, including their challenges into themes (Table 2). This is based on the development of the themes on a low inference simple qualitative descriptive approach recommended by Sandelowski and Leeman 2012 [7], and then uses the themes to summarize the challenges in early neurological care for TSCls captured in the selected literature under review. Reporting involved recommending for an individualized physiotherapy administered therapeutic hypothermia following a TSCl as a key addition to guidelines for the early neurological care of TSCls.

\subsection{Stage Six: Consultation Exercise}

The sixth and final stage of this review involved a consultation meeting with the healthcare team members involved in the care of TSCl. The 18man consultation panel was made up with Two (2) consultant neurologists, one (1) nurse, one (1) laboratory scientist, one (1) statistician, two (2) informed TSCl patients, Nine (9) 
physiotherapists and the three authors (physiotherapists). Discussions on further studies were made and agreement to exclude them from the scoping review was made.

\section{RESULTS}

Twenty-eight (28) studies (Table 1) were reviewed. Most [19] of the studies were systematic reviews of current literature. Four studies used prospective methods, 2 studies both used retrospective and reviews of guideline, and one used cross sectional survey method. In each of the studies, various acute stage interventions were reviewed to outline common standards and recommendations for clinical practices with highlights on their challenges. Various acute stage interventions cited include pre-hospital immobilization and transportation (7 papers), bed reduction (2 papers), hemodynamic stability: Use of vasopressors (7 papers), corticosteroids: MPS (10 papers), neuroprotective strategies: Fibroblast growth factor, minocycline, riluzole, cytokine granulocyte colony stimulating factor, TH (4 papers), neuroregenerative therapies: Embryonic stem cells, Induced pluripotent stem cells, olfactory ensheathing cells, Schwann cells, mesenchymal cells and activated autologous macrophages (2 papers), intubation (2 papers), Surgical decompression (16 papers), surgical fixation and fusion (9 papers), rehabilitation (5 papers), and radiological assessment-MRI (5 papers).

Of the 28 studies reviewed, surgical timing was the most cited challenges $(\mathrm{N}=12,42.9 \%)$, followed by controversies on the use of MPS $(\mathrm{N}=8 ; 28.6 \%)$. TH was mentioned as an example of neuroprotective strategies in four of the papers reviewed. Surgical intervention is the most studied intervention. Most of the works were done in Canada; none was carried out in Africa. It was clear across the reviewed articles that no intervention has been successfully implemented to produce replicable neurological outcomes across various presentation of TSCI [13,26-58]. Several challenges and gaps in literatures have been cited to be associated with this lack of standardization of care, decreasing the heterogeneity of management strategies, and poor data for clinicians to make evidenceinformed decisions. In the sections that follow, the different multidisciplinary interventions, as well as their themes in the various domains are presented accordingly.

\subsection{Pre-hospital Immobilization and Transport}

Immediately after $\mathrm{TSCl}$ what comes to mind is extrication and transportation to the nearest spinal centre. A long standing guideline had been spelt out on best practice for spinal immobilization and transportation. However, these guidelines are not without challenges. Some of the key challenges cited include; lack of class I or II evidence supporting the use of a rigid cervical collar. Rather, worse outcome is gotten in cases with penetrating trauma, because the process of immobilization could delay life-saving resuscitation $(\mathrm{N}=2,7.1 \%)$. The Challenges with fast and efficient patient care for prompt transfer to a hospital $(\mathrm{N}=1,3.6 \%)$, mitigates Theodore et al., 2013 [29] recommendation that the most rapid means available should be used to transport patient with an acute cervical $\mathrm{TSCl}$ to the nearest capable medical facility with the mode of transportation that is based on the patient's clinical circumstances, distance from target facility, immobilization and respiratory support available during transport. These challenges are worse in developing countries which are characterized with poor access to equipment, lack of knowledge, poor data, poor transportation, and delays to presentation within 8-24 hour $(\mathrm{N}=3,10.7 \%)$. As such, disparities between the developing and developed worlds capacity to deliver emergency and acute care are most evident immediately following a TSCI [30].

A closely related intervention is postural or bed reduction, which is considered safe and essential in the management of $\mathrm{SCl}$ with loss of alignment, at least as an initial step in the overall care [31]. The Challenges cited on postural reduction includes; the risk of tissue necrosis which may occur from pressure of the rigid backboard and collars during prolonged transport, and/or short periods of rigid immobilization. Also, risks of aspiration, pressure sores and increased intracranial pressure $(5,17.9 \%)$. Besides, bed reduction is obsolete and now replaced with more aggressive medical and surgical interventions $(\mathrm{N}=1,3.6 \%)$. No outcome data has sufficed as evidence-based improvement in $\mathrm{SCl}$ outcomes for all side of controversy [31]. However, in one of the study by Kornhall et al. [48], there was no reason to abandon the current practice of spinal immobilization in patients with potential $\mathrm{SCl}$, but recommended maintaining a selective approach to the use of the various stabilization devices. 
Table 1. Details of primary studies identified and reviewed

\begin{tabular}{|c|c|c|c|c|c|c|c|}
\hline $\begin{array}{l}\mathrm{S} / \\
\mathrm{n}\end{array}$ & Author, year & $\begin{array}{l}\text { Country of } \\
\text { origin }\end{array}$ & Study aim & Interventions & $\begin{array}{l}\text { Challenges and benefits } \\
\text { cited }\end{array}$ & $\begin{array}{l}\text { Study } \\
\text { design, } \\
\text { methods \& } \\
\text { sample size }\end{array}$ & $\begin{array}{l}\text { Summary of the } \\
\text { findings }\end{array}$ \\
\hline 1 & $\begin{array}{l}\text { Thomas m. } \\
\text { Kessler et al. } \\
2018 \text { [20] }\end{array}$ & $\begin{array}{l}\text { Switzerland, } \\
\text { Canada, } \\
\text { Australia }\end{array}$ & $\begin{array}{l}\text { To identify the } \\
\text { relevant aspects } \\
\text { of the early } \\
\text { neurological care } \\
\text { emphasizing } \\
\text { common } \\
\text { standards. }\end{array}$ & $\begin{array}{l}\text { Pre-hospital transportation } \\
\text { and immobilization (use of } \\
\text { backboard, cervical collar), } \\
\text { decompression, } \\
\text { fixation/stabilization and } \\
\text { fusion, early active } \\
\text { rehabilitation, vassopressor, } \\
\text { hemodynamic, MPS. }\end{array}$ & $\begin{array}{l}\text { A. Inherent risks and } \\
\text { complications in } \\
\text { immobilization, such as } \\
\text { high risk of aspiration, } \\
\text { pressure sores and } \\
\text { increased intracranial } \\
\text { pressure. } \\
\text { B. Poor transportation } \\
\text { within } 8-24 \mathrm{~h} \\
\text { C. There is no international } \\
\text { consensus for the } \\
\text { application of mps. } \\
\text { D. Decompression timing }\end{array}$ & $\begin{array}{l}\text { A systematic } \\
\text { review of } \\
\text { relevant } \\
\text { literatures. }\end{array}$ & $\begin{array}{l}\text { Early treatment, } \\
\text { prevention of } \\
\text { associated } \\
\text { complications and } \\
\text { individualized } \\
\text { patient-targeted } \\
\text { rehabilitation } \\
\text { programs are } \\
\text { crucial to optimize } \\
\text { the outcome after } \\
\text { sci. }\end{array}$ \\
\hline 2 & $\begin{array}{l}\text { J. K. Yue et } \\
\text { al. (2017) [45] }\end{array}$ & USA & $\begin{array}{l}\text { To evaluates } \\
\text { existing guidelines } \\
\text { and updates the } \\
\text { evidence for } \\
\text { prehospital } \\
\text { transport, } \\
\text { immobilization, } \\
\text { initial } \\
\text { resuscitation, } \\
\text { critical care, } \\
\text { hemodynamic } \\
\text { stability, } \\
\text { diagnostic } \\
\text { imaging, surgical } \\
\text { techniques, and } \\
\text { timing appropriate }\end{array}$ & $\begin{array}{l}\text { Prehospital transport, } \\
\text { immobilization, initial } \\
\text { resuscitation, critical care, } \\
\text { hemodynamic stability, } \\
\text { Diagnostic imaging, surgical } \\
\text { techniques }\end{array}$ & $\begin{array}{l}\text { A. Maintenance of mean } \\
\text { arterial pressure of }>85 \\
\mathrm{~mm} \text { hg } \\
\text { Optimize neurological } \\
\text { outcome } \\
\text { B. Risks of increased } \\
\text { cardiogenic complication } \\
\text { with vasopressors }\end{array}$ & $\begin{array}{l}\text { A review of } \\
\text { published } \\
\text { guidelines. }\end{array}$ & $\begin{array}{l}\text { Initial } \\
\text { management } \\
\text { should be } \\
\text { systematic, with } \\
\text { focus on spinal } \\
\text { immobilization, } \\
\text { timely transport, } \\
\text { and optimizing } \\
\text { perfusion to the } \\
\text { spinal cord. }\end{array}$ \\
\hline
\end{tabular}




\begin{tabular}{|c|c|c|c|c|c|c|c|}
\hline $\begin{array}{l}\mathrm{S} / \\
\mathrm{n}\end{array}$ & Author, year & $\begin{array}{l}\text { Country of } \\
\text { origin }\end{array}$ & Study aim & Interventions & $\begin{array}{l}\text { Challenges and benefits } \\
\text { cited }\end{array}$ & $\begin{array}{l}\text { Study } \\
\text { design, } \\
\text { methods \& } \\
\text { sample size } \\
\end{array}$ & $\begin{array}{l}\text { Summary of the } \\
\text { findings }\end{array}$ \\
\hline & & & $\begin{array}{l}\text { for the patient with } \\
\mathrm{SCl} \text { who has } \\
\text { multisystem } \\
\text { trauma. }\end{array}$ & & & & \\
\hline 3 & $\begin{array}{l}\text { Rouanetc et } \\
\text { al. } 2017 \text { [17] }\end{array}$ & Brazil & $\begin{array}{l}\text { To elucidate } \\
\text { current concepts } \\
\text { And treatment } \\
\text { update in tscis }\end{array}$ & $\begin{array}{l}\text { Surgical decompression, } \\
\text { methylprednisolone( mps), } \\
\text { Neuroprotective(hypothermi } \\
\text { a, fibroblast growth factor, } \\
\text { minocycline, riluzole, } \\
\text { cytokine granulocyte colony } \\
\text { stimulating factor), } \\
\text { Neuroregenerative } \\
\text { therapies ( embryonic stem } \\
\text { cells, } \\
\text { Induced pluripotent stem } \\
\text { cells, olfactory ensheathing } \\
\text { cells, } \\
\text { Schwann cells, } \\
\text { mesenchymal cells, and } \\
\text { activated autologous } \\
\text { Macrophages) }\end{array}$ & $\begin{array}{l}\text { Mps showed no long-term } \\
\text { benefits. Besides, it } \\
\text { increases gastrointestinal } \\
\text { hemorrhage } \\
\& \text { has a trend to increase } \\
\text { overall adverse events. } \\
\text { B.challanges of ongoing } \\
\text { recommendation for } \\
\text { surgical decompression in } \\
\text { the first } 24 \text { hours. } \\
\text { C. Cellular transplantation } \\
\text { remains an investigational } \\
\text { and experimental therapy, } \\
\text { with no formal } \\
\text { recommendations yet. }\end{array}$ & $\begin{array}{l}\text { A literature } \\
\text { review, } n= \\
4,346 \text { articles } \\
\text { screened. }\end{array}$ & $\begin{array}{l}\text { Key early } \\
\text { interventions are } \\
\text { increasingly being } \\
\text { recognized: } \\
\text { combined } \\
\text { neuroprotective } \\
\text { and } \\
\text { neuroregenerative } \\
\text { care are probably } \\
\text { more effective and } \\
\text { they inspire } \\
\text { current and future } \\
\text { research. }\end{array}$ \\
\hline 4 & $\begin{array}{l}\text { Fehlings et al. } \\
2017 \text { [38] }\end{array}$ & $\begin{array}{l}\text { Canada, } \\
\text { USA, } \\
\text { England }\end{array}$ & $\begin{array}{l}\text { To develop } \\
\text { recommendations } \\
\text { on the timing of } \\
\text { surgical } \\
\text { decompression in } \\
\text { patients with } \\
\text { traumatic SCl and } \\
\text { central cord } \\
\text { syndrome. }\end{array}$ & Surgical decompression & $\begin{array}{l}\text { There were no significant } \\
\text { differences in } \\
\text { Length of acute } \\
\text { care/rehabilitation stay } \\
\text { between treatment groups }\end{array}$ & $\begin{array}{l}\text { A systematic } \\
\text { review of } \\
\text { literature. }\end{array}$ & $\begin{array}{l}\text { We suggest that } \\
\text { early surgery be } \\
\text { considered as a } \\
\text { treatment option in } \\
\text { patients with } \\
\text { traumatic central } \\
\text { cord syndrome" } \\
\text { and "we suggest } \\
\text { that early surgery } \\
\text { be offered as an }\end{array}$ \\
\hline
\end{tabular}




\begin{tabular}{|c|c|c|c|c|c|c|c|}
\hline $\begin{array}{l}\mathrm{S} / \\
\mathrm{n}\end{array}$ & Author, year & $\begin{array}{l}\text { Country of } \\
\text { origin }\end{array}$ & Study aim & Interventions & $\begin{array}{l}\text { Challenges and benefits } \\
\text { cited }\end{array}$ & $\begin{array}{l}\text { Study } \\
\text { design, } \\
\text { methods \& } \\
\text { sample size }\end{array}$ & $\begin{array}{l}\text { Summary of the } \\
\text { findings }\end{array}$ \\
\hline & & & & & & & $\begin{array}{l}\text { option for acute } \\
\text { sci." Quality of } \\
\text { evidence for both } \\
\text { recommendations } \\
\text { was considered } \\
\text { low. }\end{array}$ \\
\hline 5 & $\begin{array}{l}\text { Fehlings et al. } \\
2017 \text { [40] }\end{array}$ & $\begin{array}{l}\text { Canada, } \\
\text { USA, } \\
\text { England, } \\
\text { Ireland, } \\
\text { Japan, } \\
\text { Australia }\end{array}$ & $\begin{array}{l}\text { To develop } \\
\text { guidelines that } \\
\text { outline the } \\
\text { appropriate type } \\
\text { and timing of } \\
\text { rehabilitation in } \\
\text { patients with acute } \\
\text { SCl. }\end{array}$ & Rehabilitation & $\begin{array}{l}\text { A. A lack } \\
\text { Of studies directly } \\
\text { evaluating the impact of } \\
\text { timing of treatment } \\
\text { On the effectiveness of } \\
\text { rehabilitation } \\
\text { B. Access to } \\
\text { Rehabilitation facilities; } \\
\text { some centers will not have } \\
\text { access to the equipment } \\
\text { needed. }\end{array}$ & $\begin{array}{l}\text { A systematic } \\
\text { review of the } \\
\text { literature }\end{array}$ & $\begin{array}{l}\text { Rehabilitation be } \\
\text { offered to } \\
\text { Patients with } \\
\text { acute SCI when } \\
\text { they are medically } \\
\text { stable and can } \\
\text { tolerate required } \\
\text { rehabilitation } \\
\text { intensity }\end{array}$ \\
\hline 6 & $\begin{array}{l}\text { Fehlings et al. } \\
2017 \text { [34] }\end{array}$ & Canada & $\begin{array}{l}\text { To identify } \\
\text { effective methods } \\
\text { to } \\
\text { Manage SCls and } \\
\text { reduce the extent } \\
\text { of future disability }\end{array}$ & $\begin{array}{l}\text { Corticosteroids, surgical } \\
\text { intervention, anticoagulation } \\
\text { prophylaxis, MRI, and } \\
\text { rehabilitation }\end{array}$ & $\begin{array}{l}\text { A. There still controversy } \\
\text { on benefit early versus late } \\
\text { surgery: as spontaneous } \\
\text { improvement could occur, } \\
\text { and because } \\
\text { decompression of a } \\
\text { "fragile" spinal cord could } \\
\text { result in neurological } \\
\text { worsening. } \\
\text { B. The evidence } \\
\text { suggesting harmful side } \\
\text { effects of mp is more } \\
\text { consistent than any } \\
\text { suggestion of clinical }\end{array}$ & $\begin{array}{l}\text { Review of } \\
\text { recent } \\
\text { guidelines }\end{array}$ & $\begin{array}{l}\text { There still remain } \\
\text { controversial } \\
\text { areas on available } \\
\text { strategies for the } \\
\text { treatment of } \mathrm{SCl} \text {, } \\
\text { including the use } \\
\text { of corticosteroids, } \\
\text { the optimal timing } \\
\text { of surgical } \\
\text { intervention, the } \\
\text { type and timing of } \\
\text { anticoagulation } \\
\text { prophylaxis, the } \\
\text { role of MRI, and }\end{array}$ \\
\hline
\end{tabular}




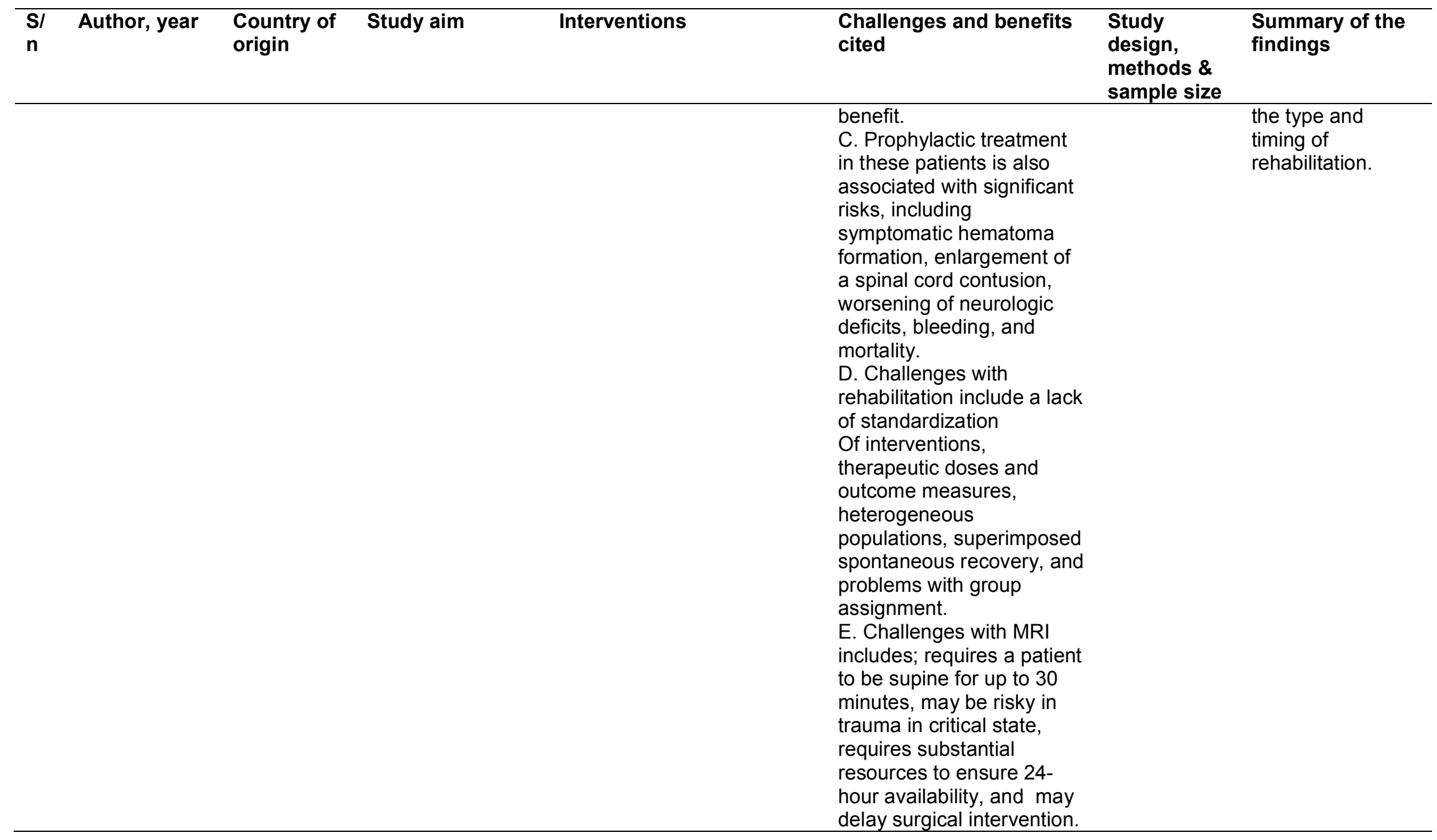




\begin{tabular}{|c|c|c|c|c|c|c|c|}
\hline $\begin{array}{l}\mathrm{S} / \\
\mathrm{n}\end{array}$ & Author, year & $\begin{array}{l}\text { Country of } \\
\text { origin }\end{array}$ & Study aim & Interventions & $\begin{array}{l}\text { Challenges and benefits } \\
\text { cited }\end{array}$ & $\begin{array}{l}\text { Study } \\
\text { design, } \\
\text { methods \& } \\
\text { sample size }\end{array}$ & $\begin{array}{l}\text { Summary of the } \\
\text { findings }\end{array}$ \\
\hline 7 & $\begin{array}{l}\text { Fehlings et al. } \\
2017 \text { [46] }\end{array}$ & $\begin{array}{l}\text { Canada, } \\
\text { USA, Japan }\end{array}$ & $\begin{array}{l}\text { To outline the } \\
\text { appropriate use of } \\
\text { methylprednisolon } \\
\text { e sodium } \\
\text { succinate (MPSS) } \\
\text { In patients with } \\
\text { acute SCls. }\end{array}$ & $\begin{array}{l}\text { Methylprednisolone sodium } \\
\text { succinate (MPSS) }\end{array}$ & Timing of MPSS infusion. & $\begin{array}{l}\text { A systematic } \\
\text { review of } \\
\text { literature. }\end{array}$ & $\begin{array}{l}\text { We suggest a 24- } \\
\text { hour infusion of } \\
\text { high-dose MPSS } \\
\text { be offered to adult } \\
\text { patients within } 8 \\
\text { hours of acute SCl } \\
\text { as a treatment } \\
\text { option. }\end{array}$ \\
\hline 8 & $\begin{array}{l}\text { Fehlings et al. } \\
2017 \text { [37] }\end{array}$ & $\begin{array}{l}\text { Canada, } \\
\text { USA, Japan }\end{array}$ & $\begin{array}{l}\text { To outline the role } \\
\text { of MRI in clinical } \\
\text { decision making } \\
\text { and outcome } \\
\text { prediction in } \\
\text { patients with } \\
\text { traumatic SCl }\end{array}$ & MRI & Timing of MRI. & $\begin{array}{l}\text { A systematic } \\
\text { review of } \\
\text { literature. }\end{array}$ & $\begin{array}{l}\text { We suggest that } \\
\text { MRI be performed } \\
\text { in adult patients } \\
\text { with acute SCl } \\
\text { prior to surgical } \\
\text { intervention, to } \\
\text { facilitate improved } \\
\text { Clinical decision- } \\
\text { making" (quality of } \\
\text { evidence, very } \\
\text { low) }\end{array}$ \\
\hline 9 & $\begin{array}{l}\text { Kreinest } \mathrm{M} \text { et } \\
\text { al. } 2017 \text { [47] }\end{array}$ & Germany & $\begin{array}{l}\text { To analyze } \\
\text { prehospital and } \\
\text { emergency room } \\
\text { care for patients } \\
\text { with acute } \\
\text { TSCl and to } \\
\text { analyze whether } \\
\text { recommendations } \\
\text { given by the } \\
\text { current guidelines } \\
\text { are implemented }\end{array}$ & $\begin{array}{l}\text { Immobilization, timely } \\
\text { transport, early surgery }\end{array}$ & Surgical timing & $\begin{array}{l}\text { Retrospectiv } \\
\text { e cohort } \\
\text { study. } \mathrm{N}= \\
133\end{array}$ & $\begin{array}{l}\text { The current study } \\
\text { shows that } \\
\text { recommendations } \\
\text { of the current } \\
\text { literature and } \\
\text { guidelines are } \\
\text { mostly followed. }\end{array}$ \\
\hline
\end{tabular}




\begin{tabular}{|c|c|c|c|c|c|c|c|}
\hline $\begin{array}{l}\mathrm{S} / \\
\mathrm{n}\end{array}$ & Author, year & $\begin{array}{l}\text { Country of } \\
\text { origin }\end{array}$ & Study aim & Interventions & $\begin{array}{l}\text { Challenges and benefits } \\
\text { cited }\end{array}$ & $\begin{array}{l}\text { Study } \\
\text { design, } \\
\text { methods \& } \\
\text { sample size }\end{array}$ & $\begin{array}{l}\text { Summary of the } \\
\text { findings }\end{array}$ \\
\hline 10 & $\begin{array}{l}\text { Kornhall et al. } \\
2017[48]\end{array}$ & Norway & $\begin{array}{l}\text { To provide a } \\
\text { national guideline } \\
\text { designed to } \\
\text { facilitate the } \\
\text { prehospital } \\
\text { Management of } \\
\text { adult trauma } \\
\text { victims with } \\
\text { potential sci. }\end{array}$ & $\begin{array}{l}\text { Prehospital management } \\
\text { (transport, immobilization), } \\
\text { spinal stabilization. }\end{array}$ & $\begin{array}{l}\text { A. Paucity of literature } \\
\text { supporting spinal } \\
\text { stabilization. } \\
\text { B. It is logical that spinal } \\
\text { stabilization in the critically } \\
\text { injured patient may cause } \\
\text { serious harm. } \\
\text { C. Victims of isolated } \\
\text { penetrating injury should } \\
\text { not be immobilized. } \\
\text { D. There is also evidence } \\
\text { suggesting harm from rigid } \\
\text { collars. } \\
\text { E. Evidence supporting } \\
\text { harm from hard surface } \\
\text { stretcher. No evidence } \\
\text { exploring spinal stability of } \\
\text { common stretcher. }\end{array}$ & $\begin{array}{l}\text { Systematic } \\
\text { review of } \\
\text { available } \\
\text { literature and } \\
\text { a } \\
\text { standardised } \\
\text { consensus } \\
\text { process. } \\
\mathrm{N}=93\end{array}$ & $\begin{array}{l}\text { The faculty found } \\
\text { no reason to } \\
\text { abandon the } \\
\text { current practice of } \\
\text { spinal } \\
\text { immobilisation in } \\
\text { patients with } \\
\text { potential SCl. } \\
\text { However, we } \\
\text { recommend } \\
\text { Maintaining a } \\
\text { selective } \\
\text { approach to the } \\
\text { use of the various } \\
\text { stabilization } \\
\text { devices. }\end{array}$ \\
\hline 11 & $\begin{array}{l}\text { N. Rath, B. } \\
\text { Balain, } 2017 \\
{[49]}\end{array}$ & UK & $\begin{array}{l}\text { To highlights the } \\
\text { main issues } \\
\text { regarding surgical } \\
\text { management of } \\
\text { acute SCl } \\
\text { patients. }\end{array}$ & $\begin{array}{l}\text { Surgical decompression, } \\
\text { fixation and stabilization, }\end{array}$ & $\begin{array}{l}\text { A. Multiple factors can } \\
\text { delay surgery } \\
\text { B.Timing of surgery }\end{array}$ & $\begin{array}{l}\text { A systematic } \\
\text { review }\end{array}$ & $\begin{array}{l}\text { It may be best to } \\
\text { consider surgery } \\
\text { within } 24 \mathrm{hr} \text { in } \\
\text { some patients, } \\
\text { provided it can be } \\
\text { safely done. } \\
\text { Otherwise } \\
\text { conservative } \\
\text { management in a } \\
\text { SCl remains the } \\
\text { safe option. }\end{array}$ \\
\hline
\end{tabular}




\begin{tabular}{|c|c|c|c|c|c|c|c|}
\hline $\begin{array}{l}\mathrm{S} / \\
\mathrm{n}\end{array}$ & Author, year & $\begin{array}{l}\text { Country of } \\
\text { origin }\end{array}$ & Study aim & Interventions & $\begin{array}{l}\text { Challenges and benefits } \\
\text { cited }\end{array}$ & $\begin{array}{l}\text { Study } \\
\text { design, } \\
\text { methods \& } \\
\text { sample size }\end{array}$ & $\begin{array}{l}\text { Summary of the } \\
\text { findings }\end{array}$ \\
\hline 12 & $\begin{array}{l}\text { Fransen } \mathrm{BL} \text { et } \\
\text { al. } 2016[50]^{0}\end{array}$ & Netherlands & $\begin{array}{l}\text { To explore pre- } \\
\text { hospital and acute } \\
\text { management of } \\
\text { TSCl in the } \\
\text { Netherlands }\end{array}$ & $\begin{array}{l}\text { Transportation, cord } \\
\text { perfusion, MRI, MPS. }\end{array}$ & $\begin{array}{l}\text { Variance in the delivery of } \\
\text { pre-hospital and acute } \\
\text { TSCI management }\end{array}$ & $\begin{array}{l}\text { Questionnair } \\
\text { e survey. } \mathrm{N}= \\
23\end{array}$ & $\begin{array}{l}\text { Survey results } \\
\text { urge the need for } \\
\text { Standardization }\end{array}$ \\
\hline 13 & $\begin{array}{l}\text { W. J. Readdy } \\
\text { et al. } 2015 \\
{[35]}\end{array}$ & USA & $\begin{array}{l}\text { To elucidate the } \\
\text { specific blood } \\
\text { pressure } \\
\text { management for } \\
\text { acute traumatic } \\
\text { central cord } \\
\text { syndrome } \\
\text { (ATCCS) and the } \\
\text { implications of } \\
\text { these } \\
\text { interventions. } \\
\text { Additionally, to } \\
\text { fully explore the } \\
\text { complications of } \\
\text { specific } \\
\text { vasopressors }\end{array}$ & $\begin{array}{l}\text { Vasopressors(dopamine, } \\
\text { phenylephrine), surgical } \\
\text { timing. }\end{array}$ & Cardiogenic complications & $\begin{array}{l}\text { A } \\
\text { retrospective } \\
\text { cohort } \\
\text { analysis of } \\
34 \text { patients } \\
\text { with ATCCS } \\
\text { who received } \\
\text { any } \\
\text { vasopressor } \\
\text { to maintain } \\
\text { map goals } \\
\text { for a mean of } \\
101 \text { hours. }\end{array}$ & $\begin{array}{l}\text { Cardiogenic } \\
\text { complications } \\
\text { associated with } \\
\text { vasopressor } \\
\text { usage were } \\
\text { notable in } 68 \% \\
\text { and neurological } \\
\text { status improved } \\
\text { by a median of } 1 \\
\text { ASIA grade in all } \\
\text { patients. }\end{array}$ \\
\hline 14 & $\begin{array}{l}\text { Ropper AE, et } \\
\text { al. } 2015 \text { [32] }\end{array}$ & USA & $\begin{array}{l}\text { To review } \\
\text { important aspects } \\
\text { of the diagnosis } \\
\text { and acute care of } \\
\text { patients with } \\
\text { TSCls, } \\
\text { emphasizing the } \\
\text { recent evidence. }\end{array}$ & $\begin{array}{l}\text { Complete spinal } \\
\text { immobilization, radiological } \\
\text { assessment, intubation, } \\
\text { vassopressors, } \\
\text { corticosteroids, surgical } \\
\text { fixation and fusion, surgical } \\
\text { decompression }\end{array}$ & $\begin{array}{l}\text { A. There is no class i or ii } \\
\text { evidence supporting the } \\
\text { use of a rigid cervical collar } \\
\text { rather worse outcome is } \\
\text { gotten in cases with } \\
\text { penetrating trauma. } \\
\text { Because the process of } \\
\text { immobilization delayed life- } \\
\text { saving resuscitation. } \\
\text { B. Cervical }\end{array}$ & $\begin{array}{l}\text { A literature } \\
\text { review }\end{array}$ & $\begin{array}{l}\text { Despite the } \\
\text { progress that has } \\
\text { been made in the } \\
\text { acute } \\
\text { management of } \\
\text { patients with } \mathrm{SCl} \text {, } \\
\text { neurological } \\
\text { outcomes have } \\
\text { not improved } \\
\text { significantly in }\end{array}$ \\
\hline
\end{tabular}




\begin{tabular}{|c|c|c|c|c|c|c|}
\hline $\begin{array}{l}\mathrm{S} / \\
\mathrm{n}\end{array}$ & Author, year & $\begin{array}{l}\text { Country of } \\
\text { origin }\end{array}$ & Interventions & $\begin{array}{l}\text { Challenges and benefits } \\
\text { cited }\end{array}$ & $\begin{array}{l}\text { Study } \\
\text { design, } \\
\text { methods \& } \\
\text { sample size }\end{array}$ & $\begin{array}{l}\text { Summary of the } \\
\text { findings }\end{array}$ \\
\hline & & & & $\begin{array}{l}\text { Collars and backboards } \\
\text { also pose risks such as } \\
\text { Aspiration, pressure sores } \\
\text { \& increased intracranial } \\
\text { pressure. } \\
\text { C. Challenges in } \\
\text { radiological study for } \\
\text { awake, symptomatic and } \\
\text { obtunded patients. } \\
\text { D. No evidence supporting } \\
\text { vassopressor, } \\
\text { corticosteroids, rather } \\
\text { corticosteroids is shown to } \\
\text { be associated with } \\
\text { pneumonia, sepsis, acute } \\
\text { respiratory distress } \\
\text { syndrome, GIT } \\
\text { haemorrhage and death. } \\
\text { E. Timing } \\
\text { Of surgery; no class I } \\
\text { evidence for early } \\
\text { decompression }\end{array}$ & & recent decades. \\
\hline 15 & $\begin{array}{l}\text { Evaniew et al. } \\
2015[51]\end{array}$ & Canada & $\begin{array}{l}\text { To determine } \\
\text { whether mps } \\
\text { improves motor } \\
\text { recovery and is } \\
\text { associated with } \\
\text { increased risks } \\
\text { For adverse } \\
\text { events. }\end{array}$ & $\begin{array}{l}\text { A. Showed no long-term } \\
\text { benefits. Besides, it } \\
\text { increases GIT bleeding } \\
\text { B. Timing of mps infusion } \\
\text { recommended to be within } \\
8 \text { hours }\end{array}$ & $\begin{array}{l}\text { A systematic } \\
\text { review and } \\
\text { meta- } \\
\text { analysis. } \\
\mathrm{N}=21\end{array}$ & $\begin{array}{l}\text { These findings } \\
\text { support current } \\
\text { guidelines against } \\
\text { routine use, but } \\
\text { strong } \\
\text { recommendations } \\
\text { are not warranted } \\
\text { because } \\
\text { confidence in the }\end{array}$ \\
\hline
\end{tabular}




\begin{tabular}{|c|c|c|c|c|c|c|c|}
\hline $\begin{array}{l}\mathrm{S} / \\
\mathrm{n}\end{array}$ & Author, year & $\begin{array}{l}\text { Country of } \\
\text { origin }\end{array}$ & Study aim & Interventions & $\begin{array}{l}\text { Challenges and benefits } \\
\text { cited }\end{array}$ & $\begin{array}{l}\text { Study } \\
\text { design, } \\
\text { methods \& } \\
\text { sample size }\end{array}$ & $\begin{array}{l}\text { Summary of the } \\
\text { findings }\end{array}$ \\
\hline & & & & & & & $\begin{array}{l}\text { effect estimates is } \\
\text { limited }\end{array}$ \\
\hline 16 & $\begin{array}{l}\text { Evaniew et al. } \\
2015[52]\end{array}$ & Canada & $\begin{array}{l}\text { To determine } \\
\text { whether } \\
\text { methylprednisolon } \\
\text { e improved motor } \\
\text { recovery. }\end{array}$ & MPS & $\begin{array}{l}\text { A. MPS did not improve } \\
\text { motor score in patients } \\
\text { with acute TSCls when the } \\
\text { influence of anatomical } \\
\text { level and severity of injury } \\
\text { were included in the } \\
\text { analysis. } \\
\text { B.there was a significantly } \\
\text { higher rate of total } \\
\text { complications }\end{array}$ & $\begin{array}{l}\text { Prospective } \\
\text { study. } \mathrm{N}=46\end{array}$ & $\begin{array}{l}\text { These findings } \\
\text { Support guideline } \\
\text { recommendations } \\
\text { against routine } \\
\text { administration of } \\
\text { methylprednisolon } \\
\text { e in acute TSCls. }\end{array}$ \\
\hline 17 & $\begin{array}{l}\text { Dvorak et al. } \\
2014[53]\end{array}$ & Canada & $\begin{array}{l}\text { To determine the } \\
\text { influence of time } \\
\text { from injury to } \\
\text { surgery on } \\
\text { neurological } \\
\text { recovery and } \\
\text { length of stay. }\end{array}$ & Surgical care & $\begin{array}{l}\text { Beneficial effect of early } \\
\text { surgery on motor recovery } \\
\text { was not seen in the } \\
\text { patients } \\
\text { With ASIA a complete SCI }\end{array}$ & $\begin{array}{l}\text { An } \\
\text { observational } \\
\text { Canadian } \\
\text { cohort study. } \\
\mathrm{N}=1410\end{array}$ & $\begin{array}{l}\text { This work } \\
\text { provides evidence } \\
\text { that for an } \\
\text { incomplete acute } \\
\text { TSCls, surgery } \\
\text { performed within } \\
24 \text { h improves } \\
\text { motor neurological } \\
\text { recovery. }\end{array}$ \\
\hline 18 & $\begin{array}{l}\text { R. R. } \\
\text { Hansebout } \\
\text { and C. R. } \\
\text { Hansebout, } \\
2014 \text { [36] }\end{array}$ & $\begin{array}{l}\text { Canada, } \\
\text { Australia }\end{array}$ & $\begin{array}{l}\text { To explore } \\
\text { effectiveness of a } \\
\text { combination of } \\
\text { steroids, } \\
\text { decompression } \\
\text { surgery, and } \\
\text { hypothermia to } \\
\text { preserve viable } \\
\text { spinal cord tissue } \\
\text { and enhance } \\
\end{array}$ & $\begin{array}{l}\text { Combination of surgical } \\
\text { decompression, } \\
\text { glucocorticoid } \\
\text { administration, and regional } \\
\text { hypothermia }\end{array}$ & $\begin{array}{l}\text { A. The optimal } \\
\text { neuroprotective } \\
\text { temperature after acute } \\
\text { trauma has not yet been } \\
\text { defined. } \\
\text { B. Cooling equipment may } \\
\text { be inaccessible }\end{array}$ & $\begin{array}{l}\text { Prospective } \\
\text { study. } \mathrm{N}=20\end{array}$ & $\begin{array}{l}\text { Given that the } \\
\text { optimal } \\
\text { neuroprotective } \\
\text { temperature after } \\
\text { acute trauma has } \\
\text { not yet been } \\
\text { defined, methods } \\
\text { that allow for the } \\
\text { early attainment of } \\
\text { such a }\end{array}$ \\
\hline
\end{tabular}




\begin{tabular}{|c|c|c|c|c|c|c|c|}
\hline $\begin{array}{l}\mathbf{S} / \\
\mathrm{n}\end{array}$ & Author, year & $\begin{array}{l}\text { Country of } \\
\text { origin }\end{array}$ & Study aim & Interventions & $\begin{array}{l}\text { Challenges and benefits } \\
\text { cited }\end{array}$ & $\begin{array}{l}\text { Study } \\
\text { design, } \\
\text { methods \& } \\
\text { sample size }\end{array}$ & $\begin{array}{l}\text { Summary of the } \\
\text { findings }\end{array}$ \\
\hline & & & $\begin{array}{l}\text { functional } \\
\text { recovery. }\end{array}$ & & & & $\begin{array}{l}\text { temperature } \\
\text { locally should be } \\
\text { further explored. }\end{array}$ \\
\hline 19 & $\begin{array}{l}\text { Theodore et } \\
\text { al. } 2013 \text { [29] }\end{array}$ & UK & $\begin{array}{l}\text { To update the } \\
\text { medical evidence } \\
\text { on the transport } \\
\text { Of patients with } \\
\text { acute SCI }\end{array}$ & $\begin{array}{l}\text { Pre-hospital transportation } \\
\text { and immobilization }\end{array}$ & $\begin{array}{l}\text { A. Lack of standard } \\
\text { transportation protocols for } \\
\text { patients with cervical spine } \\
\text { and sci. } \\
\text { B. Transportation time- 2-h } \\
\text { interval to spinal injury } \\
\text { centers. } \\
\text { C. Careful movement and } \\
\text { the use of appropriate } \\
\text { extrication } \\
\text { Techniques are crucial in } \\
\text { all mechanisms of injury } \\
\text { with the potential to cause } \\
\text { SCls. } \\
\text { D. Airplane air is less } \\
\text { humid. }\end{array}$ & $\begin{array}{l}\text { A review of } \\
\text { literature. } \mathrm{N}= \\
16\end{array}$ & $\begin{array}{l}\text { The patient with } \\
\text { an acute cervical } \\
\text { SCl should be } \\
\text { Carefully } \\
\text { transported to the } \\
\text { nearest capable } \\
\text { medical facility. } \\
\text { The mode of } \\
\text { transportation } \\
\text { should be based } \\
\text { on the patient's } \\
\text { clinical } \\
\text { circumstances, } \\
\text { distance from } \\
\text { target facility, the } \\
\text { most rapid means } \\
\text { available. } \\
\text { Immobilization of } \\
\text { patients with acute } \\
\text { cervical SCl is } \\
\text { recommended. } \\
\text { Respiratory } \\
\text { support should be } \\
\text { available during } \\
\text { transport. }\end{array}$ \\
\hline 20 & $\begin{array}{l}\text { Jefferson R. } \\
\text { Wilson, et al. } \\
2013 \text { [41] }\end{array}$ & Canada & $\begin{array}{l}\text { To review relevant } \\
\text { pathophysiology } \\
\text { and recent }\end{array}$ & $\begin{array}{l}\text { Neuroprotective therapies, } \\
\text { Neuroregenerative, } \\
\text { stabilization, }\end{array}$ & $\begin{array}{l}\text { A.bed reduction is obsolete } \\
\text { and now replaced with } \\
\text { more aggressive medical }\end{array}$ & $\begin{array}{l}\text { A review of } \\
\text { literature. } \mathrm{N}= \\
45\end{array}$ & $\begin{array}{l}\text { Treating } \mathrm{SCl} \text { is } \\
\text { relevant not only } \\
\text { to spine surgeons }\end{array}$ \\
\hline
\end{tabular}




\begin{tabular}{|c|c|c|c|c|c|c|c|}
\hline $\begin{array}{l}\text { SI } \\
\mathbf{n}\end{array}$ & Author, year & $\begin{array}{l}\text { Country of } \\
\text { origin }\end{array}$ & Study aim & Interventions & $\begin{array}{l}\text { Challenges and benefits } \\
\text { cited }\end{array}$ & $\begin{array}{l}\text { Study } \\
\text { design, } \\
\text { methods \& } \\
\text { sample size }\end{array}$ & $\begin{array}{l}\text { Summary of the } \\
\text { findings }\end{array}$ \\
\hline & & & $\begin{array}{l}\text { evidence } \\
\text { pertaining to the } \\
\text { medical, surgical } \\
\text { And cellular-based } \\
\text { treatment of acute } \\
\text { TSCls }\end{array}$ & $\begin{array}{l}\text { Decompression, } \\
\text { Hemodynamic support, } \\
\text { MPSS, therapeutic } \\
\text { hypothermia, vasopressor, }\end{array}$ & $\begin{array}{l}\text { and surgical interventions. } \\
\text { B. MPS not a standard of } \\
\text { care and may be } \\
\text { associated with an } \\
\text { increased risk of } \\
\text { complications. } \\
\text { C. The safety of } \\
\text { neuroprotectiveand } \\
\text { Neuroregenerativetherapie } \\
\text { s, is under study in early } \\
\text { phase clinical trials, but is } \\
\text { currently purely an } \\
\text { investigational therapy. } \\
\text { C. Surgical timing } \\
\text { d.Perioperative } \\
\text { hemodynamic changes } \\
\text { could } \\
\text { Compromise cord } \\
\text { perfusion } \\
\text { E. TH showed neurologic } \\
\text { recovery rate of } 20 \% \text {. } \\
\text { Although there is currently } \\
\text { Insufficient evidence to } \\
\text { support the its use }\end{array}$ & & $\begin{array}{l}\text { and physiatrists, } \\
\text { but also to the } \\
\text { general clinician } \\
\text { who will } \\
\text { increasingly } \\
\text { encounter such } \\
\text { patients in the } \\
\text { emergency } \\
\text { department or } \\
\text { family practice. }\end{array}$ \\
\hline 21 & $\begin{array}{l}\text { Fehlings MG, } \\
\text { et al. } 2012 \\
{[54]}\end{array}$ & $\begin{array}{l}\text { Canada, } \\
\text { USA }\end{array}$ & $\begin{array}{l}\text { To evaluate the } \\
\text { relative } \\
\text { effectiveness of } \\
\text { early versus late } \\
\text { Decompressive } \\
\text { surgery after }\end{array}$ & Surgical decompression & $\begin{array}{l}\text { Controversy on what other } \\
\text { factors could influence } \\
\text { outcome. }\end{array}$ & $\begin{array}{l}\text { A } \\
\text { multicenter, } \\
\text { international, } \\
\text { prospective } \\
\text { cohort study. } \\
\mathrm{N}=313\end{array}$ & $\begin{array}{l}\text { Decompression } \\
\text { prior to } 24 \text { hours } \\
\text { after SCl is } \\
\text { associated with } \\
\text { improved } \\
\text { neurologic }\end{array}$ \\
\hline
\end{tabular}




\begin{tabular}{|c|c|c|c|c|c|c|c|}
\hline $\begin{array}{l}\mathrm{S} / \\
\mathrm{n}\end{array}$ & Author, year & $\begin{array}{l}\text { Country of } \\
\text { origin }\end{array}$ & Study aim & Interventions & $\begin{array}{l}\text { Challenges and benefits } \\
\text { cited }\end{array}$ & $\begin{array}{l}\text { Study } \\
\text { design, } \\
\text { methods \& } \\
\text { sample size }\end{array}$ & $\begin{array}{l}\text { Summary of the } \\
\text { findings }\end{array}$ \\
\hline & & & TSCls & & & & $\begin{array}{l}\text { outcome, defined } \\
\text { as at least a } 2 \\
\text { grade ASIA } \\
\text { improvement at } 6 \\
\text { months follow-up. }\end{array}$ \\
\hline 22 & $\begin{array}{l}\text { Ahmed M. } \\
\text { Raslan and } \\
\text { Andrew N. } \\
\text { Nemecek, } \\
2012 \text { [31] }\end{array}$ & USA & $\begin{array}{l}\text { To review the } \\
\text { controversy } \\
\text { surrounding } \\
\text { reduction, } \\
\text { prereduction MRI, } \\
\text { timing of surgical } \\
\text { intervention and } \\
\text { the choice of } \\
\text { surgical approach. }\end{array}$ & $\begin{array}{l}\text { reduction, decompression, } \\
\text { and stabilization, MRI }\end{array}$ & $\begin{array}{l}\text { A. Controversy } \\
\text { surrounding the timing of } \\
\text { surgery remains } \\
\text { unresolved. } \\
\text { B. No outcome data has } \\
\text { suffice as evidence-based } \\
\text { improvement in SCl } \\
\text { outcomes for all side of } \\
\text { controversy. }\end{array}$ & $\begin{array}{l}\text { A review of } \\
\text { current } \\
\text { literature }\end{array}$ & $\begin{array}{l}\text { Presurgical } \\
\text { reduction is } \\
\text { considered safe } \\
\text { and essential in } \\
\text { the management } \\
\text { of } \mathrm{SCl} \text { with loss of } \\
\text { alignment, at least } \\
\text { as an initial step in } \\
\text { the overall care. }\end{array}$ \\
\hline 23 & $\begin{array}{l}\text { Anthony S. } \\
\text { Burns, and } \\
\text { Colleen } \\
\text { O'connell, } \\
2012 \text { [30] }\end{array}$ & Canada & $\begin{array}{l}\text { To highlight } \\
\text { differences in } \\
\text { global } \\
\text { epidemiology of } \\
\text { SCl and the } \\
\text { ongoing } \\
\text { challenges in } \\
\text { meeting the needs } \\
\text { of individuals with } \\
\text { SCl in the } \\
\text { developing world, } \\
\text { including post- } \\
\text { disaster. }\end{array}$ & $\begin{array}{l}\text { Immobilization, } \\
\text { transportation, rehabilitation }\end{array}$ & $\begin{array}{l}\text { Developing countries are } \\
\text { characterized with poor } \\
\text { access to equipment, lack } \\
\text { of knowledge, poor data, } \\
\text { delays to presentation are } \\
\text { common. }\end{array}$ & $\begin{array}{l}\text { A literature } \\
\text { review }\end{array}$ & $\begin{array}{l}\text { Disparities } \\
\text { between the } \\
\text { developing and } \\
\text { developed } \\
\text { Worlds capacity to } \\
\text { deliver emergency } \\
\text { and acute care } \\
\text { Are most evident } \\
\text { immediately } \\
\text { following a SCl. }\end{array}$ \\
\hline 24 & $\begin{array}{l}\text { Felleiter et al. } \\
2012[55]\end{array}$ & Switzerland & $\begin{array}{l}\text { To examine the } \\
\text { differences in the } \\
\text { use of the } \\
\text { Mps protocol for }\end{array}$ & MPS & $\begin{array}{l}\text { No differences is observed } \\
\text { in the neurological } \\
\text { outcome between the } \\
\text { different guideline of }\end{array}$ & $\begin{array}{l}\text { A } \\
\text { retrospective } \\
\text { cohort study. } \\
\mathrm{N}=226 \text {. }\end{array}$ & $\begin{array}{l}\text { The use of high- } \\
\text { dose mps has } \\
\text { reduced after the } \\
\text { publication of new }\end{array}$ \\
\hline
\end{tabular}




\begin{tabular}{|c|c|c|c|c|c|c|c|}
\hline $\begin{array}{l}\mathbf{S} / \\
\mathrm{n}\end{array}$ & Author, year & $\begin{array}{l}\text { Country of } \\
\text { origin }\end{array}$ & Study aim & Interventions & $\begin{array}{l}\text { Challenges and benefits } \\
\text { cited }\end{array}$ & $\begin{array}{l}\text { Study } \\
\text { design, } \\
\text { methods \& } \\
\text { sample size }\end{array}$ & $\begin{array}{l}\text { Summary of the } \\
\text { findings }\end{array}$ \\
\hline & & & $\begin{array}{l}\text { TSCls before and } \\
\text { after the } \\
\text { publication of new } \\
\text { guidelines in } \\
\text { Switzerland. }\end{array}$ & & $\begin{array}{l}\text { increased and decreased } \\
\text { mps use }\end{array}$ & & $\begin{array}{l}\text { guidelines. } \\
\text { Despite these } \\
\text { changes, no } \\
\text { differences in the } \\
\text { neurological } \\
\text { outcome were } \\
\text { detected between } \\
\text { the observed } \\
\text { patient } \\
\text { populations. }\end{array}$ \\
\hline 25 & $\begin{array}{l}\text { Goulet et al. } \\
2011[39]\end{array}$ & Canada & $\begin{array}{l}\text { To answer } 3 \\
\text { specific questions: } \\
(1) \text { what is the } \\
\text { recommended } \\
\text { protocol for MRI } \\
\text { in acute SCI? (2) } \\
\text { does MRI affect } \\
\text { the initial } \\
\text { management? } \\
\text { (3) does MRI } \\
\text { predict a patient's } \\
\text { long-term } \\
\text { neurological } \\
\text { outcome? }\end{array}$ & MRI & $\begin{array}{l}\text { A. The logistics of patient } \\
\text { transport and monitoring. } \\
\text { B. May be risky in trauma } \\
\text { patients in critical } \\
\text { condition, c. May delay } \\
\text { surgical intervention }\end{array}$ & $\begin{array}{l}\text { A } \\
\text { systematicall } \\
\text { y review of } \\
\text { literature. } \mathrm{N}= \\
113 .\end{array}$ & $\begin{array}{l}\text { Based on the } \\
\text { literature, the } \\
\text { exact time to } \\
\text { perform an MRI } \\
\text { within the acute } \\
\text { period cannot be } \\
\text { determined }\end{array}$ \\
\hline 26 & $\begin{array}{l}\text { Furlan et al. } \\
2011[56]\end{array}$ & Canada & $\begin{array}{l}\text { To critically review } \\
\text { the literature on } \\
\text { the potential } \\
\text { impact of timing of } \\
\text { surgical } \\
\text { decompression } \\
\text { outcomes after }\end{array}$ & Surgical decompression & $\begin{array}{l}\text { A number of studies } \\
\text { indicated that patients who } \\
\text { undergo early } \\
\text { Surgery can have similar } \\
\text { outcomes to patients who } \\
\text { received a delayed surgery } \\
\text { B. The optimal timing of }\end{array}$ & $\begin{array}{l}\text { Reviews of } \\
\text { pre-clinical } \\
\text { and clinical } \\
\text { evidence. } \\
\mathrm{N}=41\end{array}$ & $\begin{array}{l}\text { Early surgical } \\
\text { intervention } \\
\text { should be } \\
\text { considered in all } \\
\text { patients from } 8 \text { to } \\
24 \text { hrs } \\
\text { Following acute }\end{array}$ \\
\hline
\end{tabular}




\begin{tabular}{|c|c|c|c|c|c|c|c|}
\hline $\begin{array}{l}\mathrm{S} / \\
\mathrm{n}\end{array}$ & Author, year & $\begin{array}{l}\text { Country of } \\
\text { origin }\end{array}$ & Study aim & Interventions & $\begin{array}{l}\text { Challenges and benefits } \\
\text { cited }\end{array}$ & $\begin{array}{l}\text { Study } \\
\text { design, } \\
\text { methods \& } \\
\text { sample size }\end{array}$ & $\begin{array}{l}\text { Summary of the } \\
\text { findings }\end{array}$ \\
\hline & & & TSCls. & & $\begin{array}{l}\text { surgery, in patients with a } \\
\text { central cord injury remains } \\
\text { unclear. }\end{array}$ & & TSCI \\
\hline 27 & $\begin{array}{l}\text { Ploumis et al. } \\
2010[57]\end{array}$ & $\begin{array}{l}\text { Greece, } \\
\text { USA, } \\
\text { Canada }\end{array}$ & $\begin{array}{l}\text { To evaluate the } \\
\text { evidence } \\
\text { supporting a role } \\
\text { for vasopressor } \\
\text { support in the } \\
\text { management of } \\
\text { acute } \mathrm{SCl} \text { and to } \\
\text { provide updated } \\
\text { recommendations } \\
\text { for appropriate } \\
\text { clinical application } \\
\text { of this modality. }\end{array}$ & Vasopressor & $\begin{array}{l}\text { There was no statististical } \\
\text { difference in neurologic } \\
\text { improvement. }\end{array}$ & $\begin{array}{l}\text { A systematic } \\
\text { review of } \\
\text { clinical and } \\
\text { preclinical } \\
\text { literature. } \\
\mathrm{N}=32\end{array}$ & $\begin{array}{l}\text { There is currently } \\
\text { no gold standard } \\
\text { on vasopressor } \\
\text { support. }\end{array}$ \\
\hline 28 & $\begin{array}{l}\text { Laura } \\
\text { Pimentel and } \\
\text { Laura } \\
\text { Diegelm, } 2010 \\
\text { [58] }\end{array}$ & USA & $\begin{array}{l}\text { To outline the } \\
\text { evaluation and } \\
\text { management of } \\
\text { blunt cervical } \\
\text { spine trauma by } \\
\text { the emergency } \\
\text { physician }\end{array}$ & $\begin{array}{l}\text { Pre-hospital transportation } \\
\text { and immobilization (use of } \\
\text { backboard, cervical collar, } \\
\text { spider straps, and } \\
\text { Head blocks, kendrick } \\
\text { extrication device), } \\
\text { intubation, MRI, closed } \\
\text { reduction, halo traction, } \\
\text { Open reduction, or } \\
\text { decompression, }\end{array}$ & $\begin{array}{l}\text { A. should therapy proceed } \\
\text { in the presence of spinal } \\
\text { and neurogenic shock. } \\
\text { B. Challenges with fast and } \\
\text { efficient care for prompt } \\
\text { transfer to a spinal center. } \\
\text { C. How to secure to the } \\
\text { backboard to minimize } \\
\text { movement in case the } \\
\text { patient vomits and needs } \\
\text { to be rolled onto the side to } \\
\text { prevent aspiration } \\
\text { D. Studies are unclear } \\
\text { regarding how long on the } \\
\text { backboard as risk for } \\
\text { developing complications. }\end{array}$ & $\begin{array}{l}\text { Review of } \\
\text { literature }\end{array}$ & $\begin{array}{l}\text { Early intervention } \\
\text { accomplishing } \\
\text { closed reduction, } \\
\text { halo traction, open } \\
\text { reduction, or } \\
\text { decompression } \\
\text { provides the best } \\
\text { patient outcomes. }\end{array}$ \\
\hline
\end{tabular}


Ede et al.; ARRB, 35(11): 1-32, 2020; Article no.ARRB.61506

\begin{tabular}{|c|c|c|c|c|c|}
\hline $\begin{array}{ll}\text { S/ } & \text { Author, year } \\
\mathrm{n} & \end{array}$ & $\begin{array}{l}\text { Country of } \\
\text { origin }\end{array}$ & Study aim Interventions & $\begin{array}{l}\text { Challenges and benefits } \\
\text { cited }\end{array}$ & $\begin{array}{l}\text { Study } \\
\text { design, } \\
\text { methods \& } \\
\text { sample size }\end{array}$ & $\begin{array}{l}\text { Summary of the } \\
\text { findings }\end{array}$ \\
\hline & & & $\begin{array}{l}\text { E. Caution is warranted } \\
\text { when considering the use } \\
\text { of phenylephrine its pure } \\
\text { stimulation of a-receptors } \\
\text { is associated } \\
\text { With reflex bradycardia }\end{array}$ & & \\
\hline
\end{tabular}




\subsection{Corticosteroids}

Methylprednisolone (MPS) use is generally a controversy across all the reviewed articles. It's most cited challenges are: Lack of supporting evidence, there is no international consensus for the application of MPS ( $\mathrm{N}=8,28.6 \%)$. Rather, MPS is shown to be associated with pneumonia, sepsis, acute respiratory distress syndrome, gastrointestinal haemorrhage and has a trend to increase overall Complication ( $\mathrm{N}=6,21.4 \%)$. And lastly, studies by Fehlings et al. [34] suggested a 24-hour infusion of high-dose MPS to be offered to adult patients within 8 hours of acute $\mathrm{SCl}$ as a treatment option. This highlighted the challenges on timing of MPS infusion within 8 hours and in the presence of other complications $(\mathrm{N}=2,7.1 \%)$.

\subsection{Hemodynamic Stability}

Many patients exhibit neurogenic shock (hypotension and bradycardia) due to a sudden loss of sympathetic outflow and relative hypovolemia. This is common in patients' with acute cervical tetraplegia or high thoracic paraplegia. This can contribute to hypoperfusion of the spinal cord and further ischemic insult. Clinical guidelines on hemodynamic stability have routinely recommended vasopressors as key for maintaining the arterial pressure within 85 to $100 \mathrm{mmHg}$. However, its challenges include lack gold standard for usage $(\mathrm{N}=2,7.1 \%)$, and there is risks of increased cardiogenic complications ( $\mathrm{N}=3,10.7 \%)$. In one of the study by Readdy et al. [35], cardiogenic complications associated with vasopressor usage were notable in $68 \%$ but Neurological status improved by a median of 1 ASIA grade in all patients.

Notwithstanding, despite the progress that has been made in the acute management of patients with $\mathrm{SCl}$, neurological outcomes has not improved significantly in recent decades $[32,33]$.

\subsection{Neuroprotective Strategies}

Key early interventions are increasingly being recognized: Combined Neuroprotective and neuroregenerative care are probably more effective and they inspire current and future research [19]. Some neuroprotective strategies cited include; Fibroblast growth factor, Minocycline, Riluzole, Cytokine granulocyte colony stimulating factor and Therapeutic Hypothermia. Challenges still abound on translating findings from this to clinical practice. Two of the studies reviewed expressed this challenges stating that the safety of Neuroprotective and neuroregenerative therapies, is under study in early phase clinical trials, but is currently purely an investigational therapy $(\mathrm{N}=2,7.1 \%)$. $\mathrm{TH}$; which is the motivation for this study, showed neurologic recovery rate of $20 \%$. Although there is currently insufficient evidence to support its use $(\mathrm{N}=2,7.1 \%)$. The optimal neuroprotective temperature after acute trauma has not yet been defined for $\mathrm{TH}(\mathrm{N}=1$, $3.6 \%$ ). Moving forward, $\mathrm{TH}$ is worthy of more focus. Given that the optimal neuroprotective temperature after acute trauma has not yet been defined, Hansebout and Hansebout [36] recommend that methods that allow for the early attainment of such a temperature locally be further explored.

\subsection{Neuroregenerative Therapies}

This also promises to be another key early intervention. Some neuroregenerative therapies cited include; embryonic stem cells, induced pluripotent stem cells, olfactory ensheathing cells, Schwann cells, mesenchymal cells, and activated autologous Macrophages. However, cellular transplantation remains an investigational and experimental therapy, with no formal recommendations yet $(\mathrm{N}=1,3.6 \%)$.

\subsection{Radiological Assessment}

The recommendations for MRI by Fehlings et al. [37] suggested that MRI be performed in adult patients with acute $\mathrm{SCl}$ prior to surgical intervention, to facilitate improved clinical decision-making. This recommendation was with very low quality of evidence, especially in consideration of the following cited challenges; radiological investigations requires a patient to be supine for up to 30 minutes, this may be risky in trauma patients in critical condition, requires substantial resources to ensure 24-hour availability, and may delay surgical intervention. $(\mathrm{N}=3,10.7 \%)$. Challenges with the logistics of patient transport and monitoring $(\mathrm{N}=1$, $3.6 \%$ ). Based on the literature, the exact time to perform an MRI within the acute period has not been determined [39].

\subsection{Surgical Interventions}

In the reviewed articles, surgical decompression was the most cited intervention recommended for an acute $\mathrm{TSCl}$ (16 papers), followed by surgical fixation and fusion (9 papers), and intubation (2 papers). The challenge with surgical 
decompression is often on the feasibility of carrying it out within the stipulated time $(<24 \mathrm{hrs}$ from injury) ( $\mathrm{N}=12,42.9 \%)$. Meanwhile, early intervention accomplishing closed reduction, halo traction, open reduction, or decompression is recommended for the best neurological outcomes [39-43]. However, despite the progress that has been made in the acute management of patients with $\mathrm{SCl}$, neurological outcomes have not improved significantly in recent decades [32]. Presently, the recommendations for early surgical intervention in clinical guidelines are mostly with low quality of evidence [38]. Other key challenge of surgical interventions that was cited is as follows: Incomplete resuscitation of patients prior to surgery may confound the influence of morbidity and mortality $(\mathrm{N}=2,7.1 \%)$. There are still controversies on benefit of early versus late surgery: As spontaneous improvement could occur and because decompression of a fragile spinal cord could result in neurological worsening $(\mathrm{N}=7,25 \%)$. Beneficial effect of early surgery on motor recovery was not seen in the patients with ASIA A complete $\mathrm{SCl}(\mathrm{N}=1,3.6 \%)$. The optimal timing of surgery, in patients with a central cord injury remains unclear as preoperative hemodynamic changes could compromise cord perfusion $(\mathrm{N}=1$, $3.6 \%)$.

Studies on surgical fixation and fusion cited challenges which include that spinal stabilization in the critically injured patient may cause other serious harm $(\mathrm{N}=1,3.6 \%)$, There is paucity of literature supporting spinal stabilization $(\mathrm{N}=1$, $3.6 \%)$, as well as whether therapy should proceed in the presence of spinal and neurogenic shock $(\mathrm{N}=1,3.6 \%)$; are all in controversy.

\subsection{Rehabilitation}

Kessler et al. [20] recommended offering rehabilitation to individuals with acute $\mathrm{SCl}$ when they are medically stable and can tolerate good rehabilitation intensity. There remain controversial areas on available strategies for the treatment of $\mathrm{SCl}$, including the type and timing of rehabilitation [40]. Especially, the gaps between the capacity of developing and developed countries to deliver emergency and acute care instantly following a $\mathrm{SCl}$ is pronounced [30]. The recommendation for rehabilitation after patient is medically stable denies it its potential role in neuroprotective strategies, including use of $\mathrm{TH}$. Early treatment, prevention of associated complications and individualized patient-targeted rehabilitation programs are crucial to optimize the outcome after SCl [33]. The cited challenges for early rehabilitation include lack of standardization of interventions, therapeutic doses and outcome measures, heterogeneous populations, superimposed spontaneous recovery and problems with group assignment ( $\mathrm{N}=1,3.6 \%)$, As well as access to Rehabilitation facilities; as some centers may not have access to the equipment needed $(\mathrm{N}=2,7.1)$. Lastly, there is lack of studies directly evaluating the impact of timing of treatment on the effectiveness of rehabilitation $(\mathrm{N}=1,3.6 \%)$.

\section{DISCUSSION}

This review has sought to emphasize a treatment modality that targets the pathophysiological process of Traumatic Spinal Cord Injury (TSCl). Studies have shown that the secondary stage of $\mathrm{SCl}$ depicts a progressive damage with underlying cellular and molecular mechanisms of tissue degeneration and repair. Such pathological process as spinal shock, neurogenic shock, vasospasm, ischemia, infarction, oxidative stress, ionic imbalance, release of vaso-active protein, excitotoxic glutamine release, neurotransmitter accumulation, neuroinflamation, increased interstitial pressures, axon demyelination, glial scar formation, matrix remodelling, lipid peroxidation, and cell death has been disclosed to be major secondary presentations of TSCls. These presentations occur within the acute phase, with the cell death and scar formation completed within the first few days $[17,18]$. Modalities to combat any of these presentations at the acute phase have potential to influence the final neurological outcome of the primary injury $[17,18]$.

The result of this study shows different facets of challenges in current acute interventions and poor supporting evidence for the neurological care of patients with TSCls. Firstly, there are limited treatment options for patients shortly after $\mathrm{TSCl}$. And more unfortunately, most of the present choices of acute care are heavily in controversy as they often lead to more complications. Generally, no outcome data has sufficed as significant improvements in neurological outcomes for all side of controversy. Presently, early surgical decompression is the most cited and accepted treatment options recommended for the best neurological outcomes [39-43]. However, challenges on surgical decompression is often on the feasibility of carrying it out within the recommended time 
( $<24$ hrs from injury). Secondly, despite the progress that has been made in surgical decompression, neurological outcomes have not improved significantly in recent decades [32]. The recommendations for early surgical intervention in clinical guidelines are mostly with low quality of evidence [38].

The argument in support of immobilisation is on SCIWORA and SCIWORET.

The Frankel E/ASIA E represents another importance of immobilization for incomplete $\mathrm{SCl}$ where patients may present with normal motor and sensory function but have a radiological evidence of SCl. It is in this case that immobilization helps to allow reduction of the spinal injuries and to avoid further injuries. Nevertheless, in cases of potential ASIA A/Frankel A SCI, there is no class I or II evidence supporting the practice of routine immobilization. Rather, the process of immobilization could delay life-saving and neuroprotective process. Similarly, many medications that had been employed to combat the presenting pathological process had shown no significant improvement in neurological outcomes: the corticosteroids, and the vassopressors, were employed to combat neuro-inflammation and neurogenic shock respectively. The major challenge of early rehabilitation is on timing determining the most appropriate time to begin rehabilitative protocols in the face of unstable vital signs, and poor clinical state [40].

The failure of improvement in $\mathrm{SCl}$ outcomes despite extensive efforts is frustrating. New focus of $\mathrm{SCl}$ intervention are on early intervention. Late interventions has been linked to poor neurological outcomes [17,18]. Besides, watching the patients without vital care to combat the ongoing pathological process at the early stage is as good as allowing nature or the normal body physiology to determine their fate. Thus, the practice of waiting for spinal shock to be over before commencing care is conceptually and scientifically part of the past.The findings of this study makes for a re-emphasis on early interventions; immediately from the accident scene, with the goal to revert the progressive damaging pathophysiological cascades (see Fig. 2). Early treatment, prevention of associated complications and individualized patient-targeted rehabilitation programs are crucial to optimize the outcome after SCl [33].

Key early interventions are increasingly being recognized: combined neuroprotective strategies and neuroregenerative therapies are potentially more effective and they inspire current and future research [19]. However, presently, there are few recommendations for the safety of neuroprotective and neuroregenerative therapies in clinical guidelines. Their interventions are currently purely an investigational therapy [45].

Key objective of this study is to draw attention to possible opportunities that could be obtained in adding $\mathrm{TH}$ in the guidelines for the acute care of TSCl. TH has been cited as one of the key neuroprotective strategy that is presently a focus in preclinical studies $[36,41]$. TH is the treatment of certain pathological conditions by the use of low temperature. TH has been successfully used to achieve significant better neurological outcomes in such conditions as; anoxic brain injury and global brain ischemia seen in cardiac arrest patients and neonatal hypoxic-ischemic encephalopathy [42]. The neuroprotection effect offered by $\mathrm{TH}$ has been attributed to reducing metabolic demand by decreasing the rate of oxygen consumption, reducing ATP demand and halting early gene expression of excitatory neurotransmitors [42]. Thus, plays a central role in preventing neuronal cell death. TH also stabilizes the vascular integrity and reduces cerebral oedema by decreasing permeability to inflammatory cytokines and potential harmful substances such as free radicals and thrombin [42]. As elucidated above for the pathophysiology of TSCl, when a tissue is injured, blood vessels surrounding it are torn, and blood cells and fluids escape into the spaces among the tissues cells and such areas presents with inflammatory response. For $\mathrm{TSCl}$, such swelling is countered by compression from the spinal bony vertebrae thus, producing a counter damaging effect.

TH applied in the form of cryotherapy produces deep cooling effect temperature will drop from skin to $\sim 2-7 \mathrm{~cm}$ deep 10 minutes [43], decreases the flow of this fluid into the tissue and slows the release of chemicals that cause pain and inflammation [44]. The associate physiological benefit of $\mathrm{TH}$ would include; improve hemodynamic, reduce nerve ending response, decreased metabolism, reduced capillary hydrostatic pressure. Improve hemodynamic would be produced according to Lewis Hunting reaction. Hunting response is a reflex increase in vasodilatation that occurs in response to cold approximately 15 minutes from vasoconstriction following the application of cold. With a continued application, the vessels walls fluctuate 
continuously from vasoconstriction to dilatation. Thus, would help correct neurogenic shock by increasing cord perfusion.

Secondly, for reduce nerve-ending response, $\mathrm{TH}$ would cause a reduced synaptic activity and increased threshold for nerve firing, thereby helping to correct vasospasm and discomforts from pain. Thirdly, on decreased metabolism; according to Vant Huff's law, "a fall in body temperature up to $1^{\circ} \mathrm{C}$ will lead to a decrease in the cellular metabolism by one eighth" [10]. This would prevent hypoxia, lipid peroxidation and associated inflammatory mediators and oxidative radicals. Also, for reduced capillary hydrostatic pressure; this would result from increased blood viscosity, reduced permeability and osmotic pressure, and preservation of the $\mathrm{Na}+, \mathrm{K}+, \mathrm{Ca}+$ channels thereby helping reduce swelling. A reduced swelling would mean a reduction in cord compression. Finally, a combine effect of the above would help correct glial scar formation, neuronal cell death and result in a better neurological outcome (see Fig. 3).

Unlike the various facets of challenges with the other outlined early interventions for TSCI (Table 2), TH is much simpler and adaptable. It would be much easier; with $\mathrm{TH}$, to promote standardization of care, decrease the heterogeneity of management strategies, and would encourage clinicians to make evidenceinformed decisions. This is because, the opportunities in TH would most perfectly mitigate the most glaring challenges of classical interventions; it would be much adapted to mitigate the challenges of timing as it could easily be administered by every member of the care team, thus, it can be administered from the prehospital stage of care alongside with transportation. Also, it can be administered simultaneously with other line of care and it has little or no cited pitfall and harmful effect; it can proceed in the presence of neurogenic shock, spinal shock, and in unconscious or critical state. Again, a development of promising acute intervention strategies from $\mathrm{TH}$ will not only be remedial but would be very feasible on clinical implementation, adaptability and; especially, in developing regions like Africa, where sophisticated equipment may not be easily accessible, a physiotherapy modality will be far reaching and potent for curbing the challenges' of TSCls and other related complications. This can drive reduced disability levels with associated healthier population, reduced cost of care, and reduced morbidity as well as mortality that is common with SCls.

Table 2. Summary of themes identified

\begin{tabular}{llcc}
\hline Interventions & Identified Themes of Challenges & $\mathbf{N}$ & $\%$ \\
\hline $\begin{array}{l}\text { Prehospital } \\
\text { immobilization and } \\
\text { transport (7 papers) }\end{array}$ & $\begin{array}{l}\text { Challenges with fast and efficient patient care for prompt } \\
\text { transfer to a hospital. }\end{array}$ & 1 & 3.6 \\
\cline { 2 - 5 } & $\begin{array}{l}\text { Tissue necrosis may occur from pressure of the rigid } \\
\text { backboard and collars during prolonged transport, and/or } \\
\text { short periods of rigid immobilization. Also, risks of aspiration, } \\
\text { pressure sores \& increased intracranial pressure }\end{array}$ & 5 & 17.9 \\
\cline { 2 - 5 } & $\begin{array}{l}\text { There is no class I or Il evidence supporting the use of a rigid } \\
\text { cervical collar rather worse outcome is gotten in cases with } \\
\text { penetrating trauma. Because the process of immobilization } \\
\text { could delay life-saving resuscitation. }\end{array}$ & 2 & 7.1 \\
\cline { 2 - 5 } & $\begin{array}{l}\text { Developing countries are characterized with poor access to } \\
\text { equipment, lack of knowledge, poor data, poor } \\
\text { transportation, and delays to presentation within 8-24 h are } \\
\text { common. }\end{array}$ & 3 & 10.7 \\
\hline $\begin{array}{l}\text { Bed reduction (2 } \\
\text { papers) }\end{array}$ & $\begin{array}{l}\text { No outcome data has suffice as evidence-based } \\
\text { improvement in SCl outcomes for all side of controversy. }\end{array}$ & 1 & 3.6 \\
\cline { 2 - 5 } & $\begin{array}{l}\text { Bed reduction is obsolete and now replaced with more } \\
\text { aggressive medical and surgical interventions. }\end{array}$ & 1 & 3.6 \\
\hline $\begin{array}{l}\text { Hemodynamic stability- } \\
\text { use of Vassopressors(7) } \\
\text { papers) }\end{array}$ & Ro gold standard on use of Vassopressors. & 3 & 10.7 \\
\hline $\begin{array}{l}\text { Corticosteroids } \\
\text { (methylprednisolone }\end{array}$ & $\begin{array}{l}\text { Rather it is shown to be associated with pneumonia, sepsis, } \\
\text { acute respiratory distress syndrome, gastrointestinal }\end{array}$ & 6 & 21.4 \\
\hline
\end{tabular}




\begin{tabular}{|c|c|c|c|}
\hline \multirow[t]{3}{*}{$\begin{array}{l}\text { sodium succinate- } \\
\text { (MPSS) (10 papers) }\end{array}$} & \multicolumn{3}{|l|}{$\begin{array}{l}\text { haemorrhage and has a trend to increase overall } \\
\text { Complication. }\end{array}$} \\
\hline & $\begin{array}{l}\text { No evidence supporting corticosteroids, and There is no } \\
\text { international consensus for the application of MPS. }\end{array}$ & 8 & 28.6 \\
\hline & Timing of MPSS infusion & 2 & 7.1 \\
\hline \multirow{3}{*}{$\begin{array}{l}\text { Neuroprotective } \\
\text { strategies (Fibroblast } \\
\text { growth factor, } \\
\text { Minocycline, Riluzole, } \\
\text { Cytokine granulocyte } \\
\text { colony stimulating } \\
\text { factor) Therapeutic } \\
\text { Hypothermia(TH),(4 } \\
\text { papers) }\end{array}$} & $\begin{array}{l}\text { The safety of Neuroprotective and neuroregenerative } \\
\text { therapies, is under study in early phase clinical trials, but is } \\
\text { currently purely an investigational therapy. }\end{array}$ & 2 & 7.1 \\
\hline & $\begin{array}{l}\text { TH showed neurologic recovery rate of } 20 \% \text {. Although there } \\
\text { is currently insufficient evidence to support its use }\end{array}$ & 2 & 7.1 \\
\hline & $\begin{array}{l}\text { The optimal neuroprotective temperature after acute trauma } \\
\text { has not yet been defined for TH }\end{array}$ & 1 & 3.6 \\
\hline $\begin{array}{l}\text { Neuroregenerative } \\
\text { therapies ( embryonic } \\
\text { stem cells, } \\
\text { induced pluripotent } \\
\text { stem cells, olfactory } \\
\text { ensheathing cells, } \\
\text { Schwann cells, } \\
\text { mesenchymal cells, } \\
\text { and activated } \\
\text { autologous } \\
\text { Macrophages)(2 } \\
\text { papers) }\end{array}$ & $\begin{array}{l}\text { Cellular transplantation remains an investigational and } \\
\text { experimental therapy, with no formal recommendations yet. }\end{array}$ & 1 & 3.6 \\
\hline \multirow[t]{7}{*}{$\begin{array}{l}\text { Surgical } \\
\text { decompression( } 16 \\
\text { papers) }\end{array}$} & $\begin{array}{l}\text { Incomplete resuscitation of patients prior to surgery may } \\
\text { confound the influence of morbidity and } \\
\text { Mortality }\end{array}$ & 2 & 7.1 \\
\hline & $\begin{array}{l}\text { There still controversy on benefit of early versus late surgery: } \\
\text { as spontaneous improvement could occur, and because } \\
\text { decompression of a "fragile" spinal cord could result in } \\
\text { neurological worsening. }\end{array}$ & 7 & 25 \\
\hline & $\begin{array}{l}\text { beneficial effect of early surgery on motor recovery was not } \\
\text { seen in the patients with ASIA A complete SCI }\end{array}$ & 1 & 3.6 \\
\hline & Surgical timing & 12 & 42.9 \\
\hline & $\begin{array}{l}\text { The optimal timing of surgery, in patients with a central cord } \\
\text { injury remains unclear }\end{array}$ & 1 & 3.6 \\
\hline & $\begin{array}{l}\text { preoperative hemodynamic changes could compromise cord } \\
\text { perfusion }\end{array}$ & 1 & 3.6 \\
\hline & $\begin{array}{l}\text { Controversy on what other factors could influence surgical } \\
\text { outcome }\end{array}$ & 2 & 7.1 \\
\hline \multirow{4}{*}{$\begin{array}{l}\text { surgical fixation and } \\
\text { fusion( } 9 \text { papers) }\end{array}$} & Surgical timing & 4 & 14.2 \\
\hline & $\begin{array}{l}\text { It is logical that spinal stabilization in the critically injured } \\
\text { patient may cause serious harm. }\end{array}$ & 1 & 3.6 \\
\hline & Paucity of literature supporting spinal stabilization. & 1 & 3.6 \\
\hline & $\begin{array}{l}\text { Should therapy proceed in the presence of spinal and } \\
\text { neurogenic shock }\end{array}$ & 1 & 3.6 \\
\hline \multirow[t]{3}{*}{$\begin{array}{l}\text { Rehabilitation( } 5 \\
\text { papers) }\end{array}$} & $\begin{array}{l}\text { a lack of standardization of interventions, therapeutic doses } \\
\text { and outcome measures, heterogeneous populations, } \\
\text { superimposed spontaneous recovery, and problems with } \\
\text { group assignment. }\end{array}$ & 1 & 3.6 \\
\hline & $\begin{array}{l}\text { a lack of studies directly evaluating the impact of timing of } \\
\text { treatment on the effectiveness of rehabilitation }\end{array}$ & 1 & 3.6 \\
\hline & Access to Rehabilitation facilities; some centers will not have & 2 & 7.1 \\
\hline
\end{tabular}


access to the equipment needed.

\begin{tabular}{llll}
\hline & access to the equipment needed. & \\
\hline Radiological & $\begin{array}{l}\text { Requires a patient to be supine for up to 30 minutes, may be } \\
\text { assessment-MRI (5 } \\
\text { papers) }\end{array}$ & $\begin{array}{l}\text { risky in trauma patients in critical condition, requires } \\
\text { substantial resources to ensure 24-hour availability, and may } \\
\text { delay surgical intervention. }\end{array}$ & 10.7 \\
\cline { 2 - 3 } & $\begin{array}{l}\text { Challenges with the logistics of patient transport and } \\
\text { monitoring }\end{array}$ & 1 & 3.6 \\
\hline
\end{tabular}

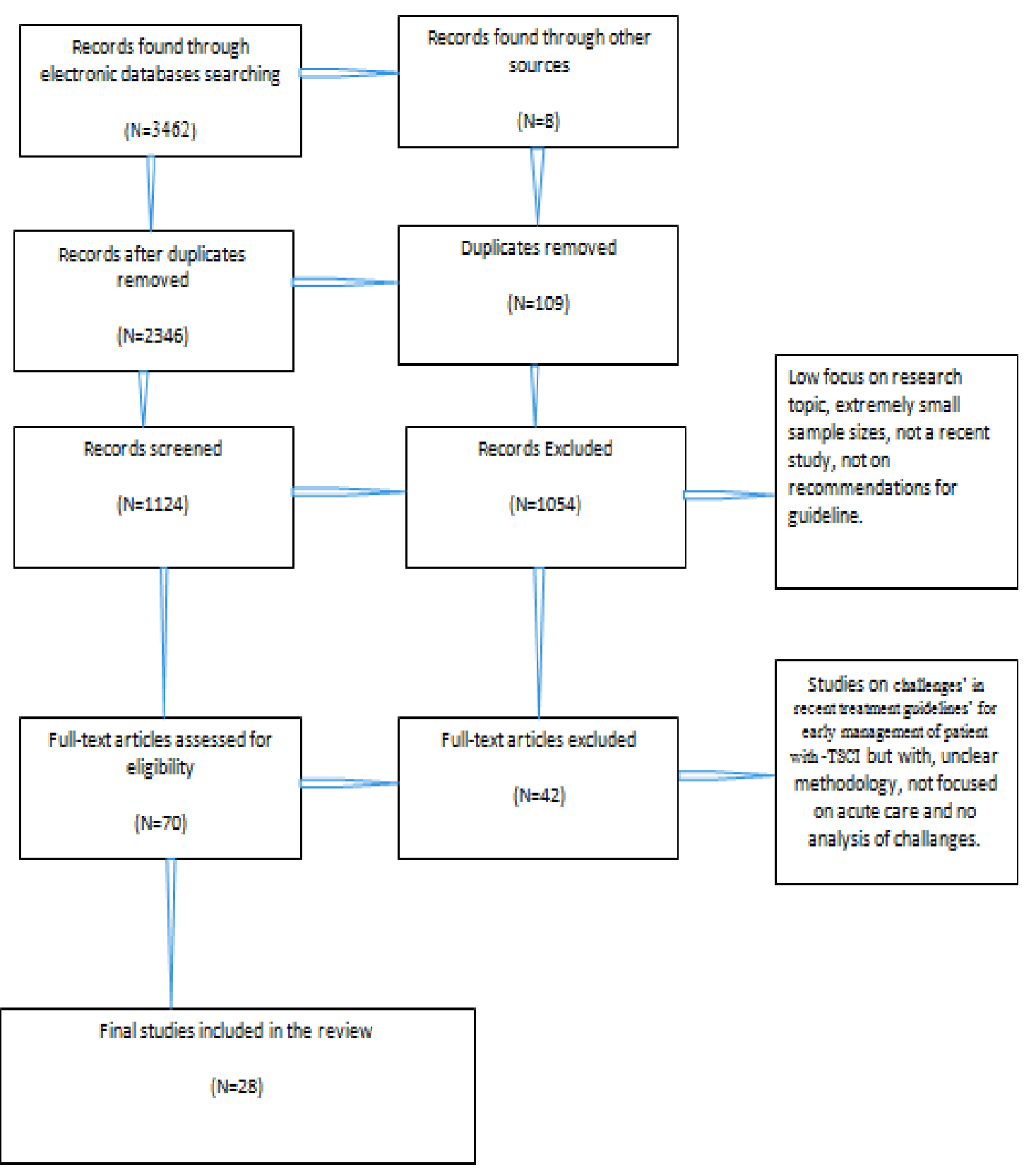

Fig. 2. PRISMA flow diagram of scoping literature search and selection 


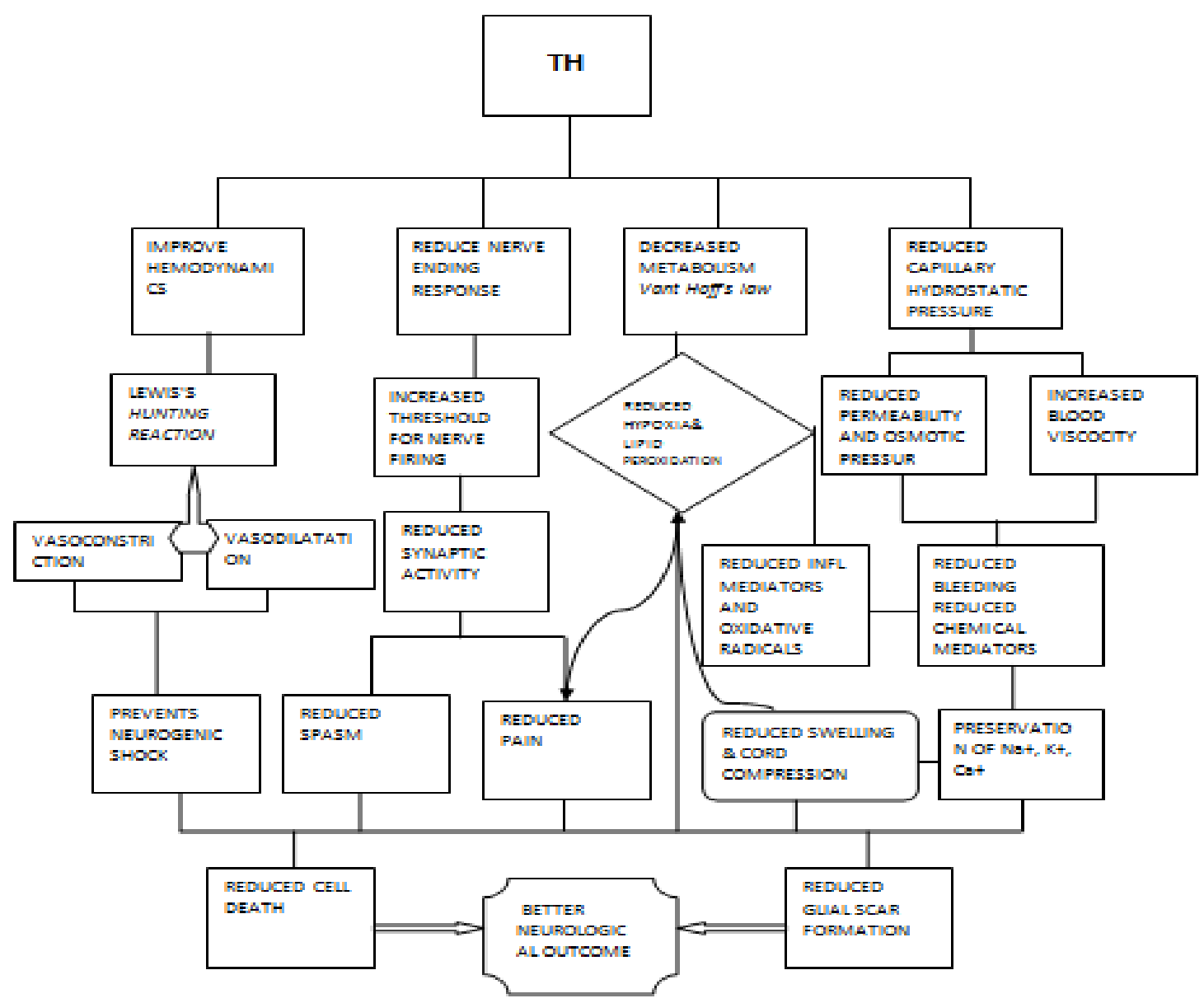

Fig. 3. Neuroprotective effects of TH

\section{LIMITATIONS OF THE REVIEW}

This review followed the vital scoping study framework proposed by Arksey and O'Malley [28]. Despite the rigorous process it adopted to engage with each of the six stages of the scoping review process, and efforts to ensure literatures in this sample is comprehensively reviewed. Despite this, there are some limitations attendant with the conduct of this review that need to be considered. The primary limitation was that the search strategy was limited to English-language studies only, and there may be other studies equally relevant to the area of challenges' in the early treatment guidelines for $\mathrm{TSCl}$ that we may not have found because it was not published in English. We also could not confirm a comprehensive list of possible lines of interventions; as such, it is possible there are emergency interventions that were not considered in this review.

\section{IMPLICATIONS FOR FURTHER RESEARCH AND PRACTICE}

Results of this review highlight the need for the acute treatment guideline of TSCI to be reviewed to increase focus on $\mathrm{TH}$ as neuroprotective strategies. The lack of evidence based guidance on the type, dose, timing, temperature; mode of applications and other related clinical parameters for $\mathrm{TH}$ necessitates future research to understudy this concept in pre-clinical and clinical trials. A prospective multi-centre longitudinal study is recommended to verify the possible neuroprotective effects of $\mathrm{TH}$ and its association with better neurological outcomes.

\section{CONCLUSION}

We collated and appraised all available published literature that investigates challenges in the early treatment guidelines for individuals 
with $\mathrm{TSCl}$ to examine how these challenges is associated with the present poor evidence based treatment option to optimise neurological outcomes following a complete TSCl. We noted the pathophysiology of the associated complications of TSCls and proposed $\mathrm{TH}$ as a key addition in the treatment guidelines for TSCls. Early intervention has been a focus of treatment for enhancing neurological recovery in TSCls. We conclude that evidence-based guidelines for $\mathrm{TH}$ would help reduce the doom experience around complete SCls. Thus, there is a need to better define the beneficial effect of $\mathrm{TH}$ on the injured $\mathrm{SCl}$, in particular as key part of neuroprotective strategies in acute care interventions for TSCls.

\section{COMPETING INTERESTS}

Authors have declared that no competing interests exist.

\section{REFERENCES}

1. World Health Organization. Spinal cord injury. WHO Fact Sheet; 2013.

Available:https://www.who.int/newsroom/fact-sheets/detail/spinal-cord-injury

2. Azeez AL, Hammed Al. Sociodemographic correlates of quality of life in spinal cord injured patients. Turk J Kinesiol. 2019;5(2):92-101.

DOI: 10.31459/turkjkin.545176

3. Singh A, Tetreault L, Kalsi-Ryan S, Nouri A, Fehlings MG. Global prevalence and incidence of traumatic spinal cord injury. Clinical Epidem. 2014;6:309.

DOI: $10.2147 / C L E P . S 68889$

4. Waters RL, Yakura JS, Adkins RH, Sie I. Recovery following complete paraplegia. Arch Phys Med Rehabil. 1992;73:784-9.

5. Van Middendorp JJ, Goss B, Urquhart S, Atresh S, Williams RP, et al. Diagnosis and prognosis of traumatic spinal cord injury. Global Spine J. 2011;1:1-8.

DOI: $10.1055 / s-0031-1296049$

6. Arsalan A, Scott MD, Soheila K. Traumatic spinal cord injury: An overview of pathophysiology, models and acute injury mechanisms. Front. Neurol. J.; 2019.

DOI:https://doi.org/10.3389/fneur.2019.002 82

7. Sandelowski M, Leeman J. Writing usable qualitative health re-search findings. Qualitative Health Research. 2012;22(10): 1404-13.

DOI: $10.1177 / 1049732312450368$
8. Fehlings MG, Vaccaro A, Wilson JR, Singh A, Cadotte WD, Harrop JS, et al. Early versus delayed decompression for traumatic cervical. Comment in Spine J. 2012;12(6):540.

DOI: 10.1371/journal.pone.0032037

9. Figley SA, Khosravi R, Legasto JM, Tseng YF, Fehlings MG. Characterization of vascular disruption and blood-spinal cord barrier permeability following traumatic spinal cord injury. J Neurotrauma. 2014;31:541-52.

DOI: $10.1089 /$ neu.2013.3034

10. Rogers CG. Studies upon the temperature coefficient of the rate of heart beat in certain living animals. Amer. Jour. of Physiol. 1911;28:81-93.

DOI: ajplegacy.1911.28.2.81

11. Cristina MK, Ramesh $\mathrm{R}$, Andrew $\mathrm{M}$. Traumatic brain and spinal cord injury: Challenges and developments. Cambridge University Press; 2012. ISBN: $1107007437,9781107007437$.

12. Wilson JR, Tetreault LA, Kwon BK, Arnold PM, Mroz TE, Shaffrey $C$, et al. Timing of decompression in patients with acute spinal cord injury: A systematic review. Global Spine J. 2017;7(3 Suppl.): 95S-115S. DOI: $10.1177 / 219256821770171620$

13. Michael FAR, Boakye M, Rossignol S, Ditunno JF, Anthony SB. Essentials of spinal cord injury basic research to clinical practice. Denver, CO: Thieme Medical Publishers Inc.; 2013.

14. Abram S, Bulstrode C. Routine spinal immobilization in trauma patients: What are the advantages and disadvantages? The Surgeon. 2010;8:218-222.

DOI: 10.1016/j.surge.2010.01.002

15. Sundstrøm T, Asbjørnsen H, Habiba S, Sunde GA, Wester K. Prehospital use of cervical collars in trauma patients: A critical review. Journal of Neurotrauma. 2014;31(6):531-540.

DOI: 10.1089/neu.2013.3094

16. Hauswald $M$, Hsu M, Stockoff C. Maximizing comfort and minimizing ischemia: A comparison of four methods of spinal immobilization. Prehospital Emergency Care. 2000;4(3):250-252. DOI: $10.1080 / 10903120090941281$

17. Tator C, Fehlings $M$. Review of the secondary injury theory of acute spinal cord trauma with emphasis on vascular mechanisms. J Neurosurg. 1991;75:15-26. DOI: 10.3171/jns.1991.75.1.0015 
18. Thumbikat $P$, Hariharan $R P$, Ravichandran G, McClelland MR, Mathew KM. Spinal cord injury in patients with ankylosing spondylitis: A 10-year review. Spine. 2007;32(26):2989-95.

DOI: 10.4103.ajns.167.13

19. Rouanet C, Reges D, Rocha E, Gagliardi V, Silva GS. Traumatic spinal cord injury: Current concepts and treatment update. Arq Neuropsiquiat. 2017;75(6):387-393.

DOI: 10.1590/0004-282X20170048

20. Thomas MK, Luca R, Traini BW, Marc PS, Jefrey T, Armin C. Early neurological care of patients with spinal cord injury. World Journal of Urology; 2018.

DOI: $10.1007 / \mathrm{s} 00345-018-2343-2$

21. Schmutzhard E, Fischer M, Dietmann A, Brössner G. Therapeutic hypothermia: The rationale. Critical Care. 2012;16.

DOI: $10.1186 /$ cc11260

22. Rivera-Lara L, Zhang J, Muehlschlegel S. Therapeutic hypothermia for acute neurological injuries: Neurotherapeutics. The Journal of the American Society for Experimental NeuroTherapeutics. 2012;9(1):73-86.

DOI: $10.1007 / \mathrm{s} 13311-011-0092-7$

23. Ahn JH, Lee TK, Kim B, Lee JC, Tae HJ, Cho JH, et al. Therapeutic hypothermia improves hind limb motor outcome and attenuates oxidative stress and neuronal damage in the lumbar spinal cord following cardiac arrest. Antioxidants. 2020;9:38.

DOI: 10.3390/antiox9010038

24. Priyanka LS, Nitin A, James CB, Robert $\mathrm{FH}$. Current therapeutic strategies for inflammation following traumatic spinal cord injury. Neural Regen Res. 2012;7(23):1812-1821.

DOI:10.3969/j.issn.1673-5374.2012.23.008

25. Joseph EM, Brian TD, Richard GF. Considerations for spinal cord injury in the athlete. Spinal Conditions in the Athlete. 2019;8:17-24.

26. Consortium for Spinal Cord Medicine. Early acute management in adults with spinal cord injury: A clinical practice guideline for health-care professionals. The Journal of Spinal Cord Medicine. 2008;31(4):403-479.

DOI:https://doi.org/10.1043/1079-0268-

31.4.408

27. Stephen B, Caroline S. Initial management of acute spinal cord injury. Continuing Education in Anaesthesia Critical Care \& Pain. 2013;13:224-231.

DOI: $10.1093 /$ bjaceaccp/mkt021
28. Arksey H, O'Malley L. Scoping studies: Towards a methodological framework. Int J Soc Res Methodol. 2005;8(1):19-32.

29. Nicholas T, Bizhan A, Sanjay SD, Daniel EG, John RH, Curtis JR, et al. Transportation of patients with acute traumatic cervical spine injuries. Neurosurgery. 2013;72:35-39. Available from the Neurosurgery Web site.

30. Anthony SB, Colleen $\mathrm{O}$. The challenge of spinal cord injury care in the developing world. The Journal of Spinal Cord Medicine. 2012;35(1).

DOI: 10.1179/2045772311Y.0000000043

31. Ahmed MR, Andrew NN. Controversies in the surgical management of spinal cord injuries. Neurology Research International. 2012;6. Article ID: 417834.

DOI: $10.1155 / 2012 / 417834$

32. Ropper AE, Neal MT, Theodore N. Acute management of traumatic cervical spinal cord injury. Pract Neurol. 2015;15:266272.

DOI: 10.1136/practneurol-2015-001094

33. Michael GF, Lindsay AT, Jefferson RW, Anthony SB, Allan RM, Gregory $\mathrm{H}$, et al. A clinical practice guideline for the management of acute spinal cord injury: Introduction, rationale and scope. Global Spine Journal. 2017;7(3S):84S-94S.

DOI: 10.31371/journal.pone.0032037

34. Fehlings MG, Wilson JR, Tetreault LA, Aarabi B, Anderson P, Arnold PM, et al. A clinical practice guideline for the management of patients with acute spinal cord injury: Recommendations on the use of methylprednisolone sodium succina. Global Spine Journal. 2017;7(3S):203S211S.

DOI: $10.1177 / 2192568217703085$

35. William JR, William DW, Adam R, Ferguson JF, Tomoo I, Rajiv S, et al. Complications and outcomes of vasopressor usage in acute traumatic central cord syndrome. J Neurosurg Spine. 2015;23:574-580.

DOI: $10.3171 / 2015.2$

36. Hansebout R, Hansebout C. Local cooling for traumatic spinal cord injury: Outcomes in 20 patients and review of the literature: Clinical article. Journal of Neurosurgery. Spine. 2014;20.

DOI: $10.3171 / 2014.2$

37. Michael GF, Allan RM, Lindsay AT, Bizhan A, Paul A, Paul MA, et al. A clinical practice guideline for the management of patients with acute spinal cord injury: 
Recommendations on the role of baseline magnetic resonance imaging in clinical decision making and outcome prediction. Global Spine Journal. 2017;7(3S):221S230S.

DOI: 10.1177/2192568217703089

38. Michael GF, Lindsay AT, Jefferson RW, Bizhan A, Paul A, Paul MA, et al. A clinical practice guideline for the management of patients with acute spinal cord injury and central cord syndrome: Recommendations on the timing ( 24 hours versus $>24$ hours) of decompressive surgery. Global Spine Journal. 2017;7(3S):195S-202S.

DOI: $10.1177 / 2192568217706367$

39. Anthony $B$, Judith $M$, Mohan R, Julie $P$, Benoit $\mathrm{G}$. The role of magnetic resonance imaging in the management of acute spinal cord injury. Journal of Neurotrauma. 2011;28:1401-1411.

DOI: 10.1089/neu.2009.1236

40. Michael GF, Lindsay AT, Bizhan A, Paul A, Paul MA, Darrel SB, et al. A clinical practice guideline for the management of patients with acute spinal cord injury: Recommendations on the type and timing of rehabilitation. Global Spine Journal. 2017;7(3S):231S-238S.

DOI: $10.1177 / 2192568217701910$

41. Jefferson RW, Nicole F, Michael GF. Emerging therapies for acute traumatic spinal cord injury. CMAJ. 2013;185(6).

DOI: $10.1503 /$ cmaj.121206

42. Song SS, Lyden PD. Overview of therapeutic hypothermia. Current Treatment Options in Neurology. 2012;14(6):541-548.

DOI: $10.1007 / \mathrm{s} 11940-012-0201-x$

43. Costello JT, Culligan K, Selfe J, Donnelly $\mathrm{AE}$. Muscle, skin and core temperature after $-110^{\circ} \mathrm{C}$ cold air and $8^{\circ} \mathrm{C}$ water treatment. PloS one. 2012;7(11):e48190.

DOI: 10.1371/journal.pone.0048190

44. Bruno F, Jeam GB, Manfredini BM, Aurélio V. Effects of cryotherapy methods on circulatory, metabolic, inflammatory and neural properties: A systematic review. Fisioter Mov. 2016;29(2).

DOI: 10.1590/0103-5150.029.002.AO18

45. John KY, Ethan AW, Jonathan WR, Hansen D, Carlene PP, Pavan SH, et al. Update on critical care for acute spinal cord injury in the setting of polytrauma. Neurosurg Focus. 2017;43(5):19. DOI: 10.3171/2017.7.FOCUS17396

46. Michael GF, Jefferson RW, Lindsay AT, Bizhan A, Paul A, Paul MA, et al. A clinical practice guideline for the management of patients with acute spinal cord injury: Recommendations on the use of methylprednisolone sodium succinate. Global Spine Journal. 2017;7(3S):203S211S.

47. Kreinest ML, Ludes AT, Grützner PA, Biglari B, Matschke S. Analysis of prehospital care and emergency room treatment of patients with acute traumatic spinal cord injury: A retrospective cohort study on the implementation of current guidelines. Spinal Cord. 2017;55:1619

DOI: $10.1038 /$ sc. 2016.84

48. Daniel KK, Jørgen JJ, Tor B, Per KH, Helge A, Thomas D, Thomas $\mathrm{H}$, et al. The Norwegian guidelines for the prehospital management of adult trauma patients with potential spinal injury. Scandinavian Journal of Trauma, Resuscitation and Emergency Medicine. 2017;25:2. DOI: 10.1186/s13049-016-0345-x

49. Rath N, Balain B. Spinal cord injury-the role of surgical treatment for neurological improvement. Journal of Clinical Orthopaedics and Trauma. 2017;8:99102.

DOI: 10.1016/j.jcot.2017.06.016

50. Fransen BL, Hosman AJ, Van-Middendorp JJ, Edwards M, Van-Grunsven PM, Vande-Meen $\mathrm{H}$. Pre-hospital and acute management of traumatic spinal cord injury in the Netherlands: Survey results urge the need for standardisation. Spinal Cord. 2016;54:34-38.

DOI: $10.1038 / \mathrm{sc} .2015 .111$

51. Nathan E, Emilie PB, Nader F, Vanessa KN, Carly SR, Marcel FD. Methylprednisolone for the treatment of patients with acute spinal cord injuries: A systematic review and meta-analysis. Journal of Neurotrauma. 2016;33:468.

DOI: 10.1089/neu.2015.4192

52. Nathan E, Vanessa KN, Nader F, Brian KK, Carly SR, Henry A, et al. Methylprednisolone for the treatment of patients with acute spinal cord injuries: A propensity score-matched cohort study from a Canadian multi-center spinal cord injury registry. Journal of Neurotrauma. 2015;32:1674-1683.

DOI: 10.1089/neu.2015.3963

53. Marcel FD, Vanessa KN, Nader F, Charles GF, Joel F, Brian KK, et al. The Influence of time from injury to surgery on motor recovery and length of hospital stay in 
acute traumatic spinal cord injury: An observational Canadian cohort study. J of Neurotrauma. 2015;32:645-654.

DOI: 10.1089/neu.2014.3632

54. Fehlings MG, Vaccaro A, Wilson JR, Singh A, Cadotte WD, Harrop JS, et al. Early versus delayed decompression for traumatic cervical spinal cord injury: Results of the surgical timing in acute spinal cord injury study (STASCIS). PLoS ONE. 2012;7(2):e32037.

DOI: 10.1371/journal.pone.0032037

55. Peter F, Nicole M, Frederik S, Olga F, Peter L. Changes in the use of the methylprednisolone protocol for traumatic spinal cord injury in Switzerland. Spine. 2012;37:953-956.

DOI: 10.1097/BRS.0b013e31823a07a2
56. Julio CF, Vanessa N, David WC, Michael GF. Timing of decompressive surgery of spinal cord after traumatic spinal cord injury: An evidence-based examination of pre-clinical and clinical studies. Journal of Neurotrauma. 2011;28:1371-1399. DOI: 10.1089/neu.2009.1147

57. Ploumis A, Yadlapalli N, Fehlings MG, Kwon BK, Vaccaro AR. A systematic review of the evidence supporting a role for vasopressor support in acute $\mathrm{SCl}$. Spinal Cord. 2010;48:356-362.

DOI: $10.1038 /$ sc.2009.150

58. Laura P, Laura D. Evaluation and management of acute cervical spine trauma. Emerg Med Clin $\mathrm{N}$ Am. 2010;28:719-738.

DOI: 10.1016/j.emc.2010.07.003

(c) 2020 Ede et al.; This is an Open Access article distributed under the terms of the Creative Commons Attribution License (http://creativecommons.org/licenses/by/4.0), which permits unrestricted use, distribution, and reproduction in any medium, provided the original work is properly cited.

Peer-review history:

The peer review history for this paper can be accessed here: http://www.sdiarticle4.com/review-history/61506 